\title{
FOREIGN INVESTMENT IN CANADA'S OIL AND GAS SECTOR: NEW AND EMERGING CHALLENGES
}

\author{
Angela Avery, Peter Glossop, \\ AND PAULA OLEXIUK*
}

Over the last few years significant investments in the Canadian resource sector have been made by foreign, state-owned investors. Recent developments in this area have raised concerns that Industry Canada is adopting a more restrictive approach with respect to state-owned enterprises. This article examines the history and evolution of Canada's foreign investment regime against the current regime in place in the energy sector. The article then examines the practical and commercial effects of the recent developments and concludes by providing examples of how to navigate the emerging commercial and regulatory framework.
Ces quelques dernières années, des intérêts étrangers ont fait d'importants investissements dans le secteur des ressources au Canada. Industrie Canada vient de modifier ses considérations d'examen incluant l'adoption d'une démarche plus restrictive quant aux entreprises d'État. Cet article examine l'historique et l'évolution du milieu réglementaire des investissements étrangers au Canada. L'article porte ensuite sur les répercussions pratiques et commerciales des derniers développements et conclut en donnant des exemples de manières de naviguer le cadre légal commercial et réglementaire émergent.

\section{TABLE OF CONTENTS}

I. INTRODUCTION . . . . . . . . . . . . . . . . . . . . . . . . . . . . . . 344

II. CANADA's EARLy UNREGULATED LANDSCAPE . . . . . . . . . . . . . . . . 344

A. EARLY TRENDS IN

FOREIGN INVESTMENT POST-CONFEDERATION . . . . . . . . . . 344

B. RAPID Foreign INVESTMENT POST-WORLd WAR II . . . . . . . . . 345

III. A MOVEMENT TOWARD RESTRICTIVE REGULATION . . . . . . . . . . . . . . . 346

A. GROWING HostiLITY AND ECONOMIC NATIONALISM . . . . . . . . . 346

B. GOVERNMENT SCRUTINY AND POLICY REPORTS . . . . . . . . . . . . 346

C. THE Foreign INVESTMENT REVIEW ACT . . . . . . . . . . . . . . . . . 348

D. The NATional EnERgy Program . . . . . . . . . . . . . . . . . . . . 349

E. The Creation of Petro-Canada

AND ALBERTA ENERGY COMPANY . . . . . . . . . . . . . . . . . . . 350

IV. Progressive RetURn to Liberalization . . . . . . . . . . . . . . . . . . . . . 351

A. DEPARTURE OF THE FOREIGN INVESTMENT REVIEW ACT

AND THE NATIONAL ENERGY PROGRAM AND THE

INTRODUCTION OF THE INVESTMENT CANADA ACT . . . . . . . . . . 351

B. Discontinuation of the Masse Policy $\ldots \ldots \ldots . . \ldots . . . . .353$

C. TRENDS AND DEVELOPMENTS

FROM THE LATE 1990S TO MID-2000s . . . . . . . . . . . . . . . . . . . 354

D. THE WILSON REPORT: 2008 . . . . . . . . . . . . . . . . . . . . . . . . . 356

V. RECENT DEVELOPMENTS:

New Questions ANd Potential CHALLENGES . . . . . . . . . . . . . . 358

A. NATIONAL SECURITy Considerations $\ldots \ldots \ldots \ldots \ldots \ldots 38$

B. BREACHES OF UNDERTAKINGS ................ 361

Peter Glossop is a partner in the Toronto office of Osler, Hoskin \& Harcourt and Paula Olexiuk is a partner in their Calgary offices. Angela Avery is the General Counsel of ConocoPhillips Canada. The authors gratefully acknowledge the assistance of Janice Buckingham, Jordan Giurlanda, and Daina Kvisle of Osler, Hoskin \& Harcourt. 


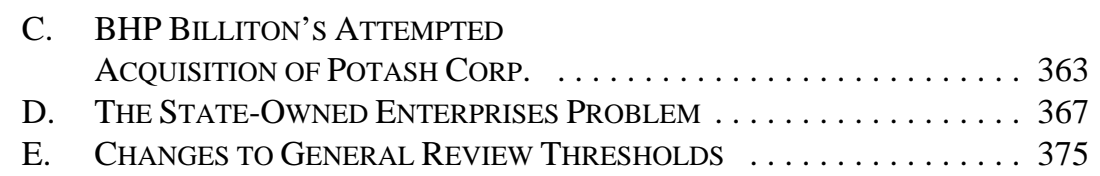

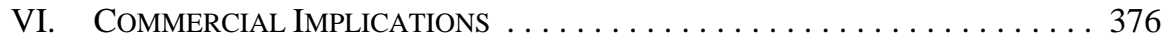
A. BENEFITS OF FOREIGN INVESTMENT
IN THE CANADIAN OIL AND GAS INDUSTRY . . . . . . . . . . . 376
B. STRUCTURING CONSIDERATIONS IN LIGHT
OF THE NEW STATE-OWNED ENTERPRISES GUIDELINES $\ldots . . \ldots$. . 377
C. WORKING WITH FOREIGN INVESTORS LOOKING TO
INVEST IN THE CANADIAN OIL AND GAS INDUSTRY . . . . . . . . . 382

\section{INTRODUCTION}

Significant investments have been made by foreign, often state-owned, investors in the Canadian resource sector in the last few years. Until very recently, foreign investors enjoyed relatively problem-free reviews of their proposed investments by Industry Canada. However, recent developments have raised concerns that Industry Canada is adopting a more restrictive posture, especially with regard to state-owned enterprises (SOEs). Increasingly, foreign investors are concerned about the complexity and uncertainty surrounding the foreign investment review process under the Investment Canada Act $^{1}$ and in particular, the federal government's application of the "net benefit" test and when "national security" considerations might apply.

This article provides a brief historical perspective on the evolution of Canada's foreign investment regime and juxtaposes this against the current landscape in the energy sector. This perspective illustrates that Canadian anxiety over foreign investment in the oil and gas sector is not a new phenomenon; the focus of attention has simply shifted from concern over investment from the United States private sector to investment from Asian SOEs.

This article also examines the practical and commercial effects of recent developments and provides examples of how to navigate the commercial and regulatory framework and manage cultural differences when acting for, and opposite to, foreign investors.

\section{CANADA’s EARLY UNREgULATED LANDSCAPE}

\section{A. EARLy TRENDS In Foreign INVESTMENT POST-CONFEDERATION}

Although protectionist policies are deeply rooted in Canadian history, foreign investment as a specific matter remained largely unregulated until 1973. Prime Minister John A. MacDonald's introduction of the National Policy in 1878 is often cited as a hallmark of Canadian economic nationalism, but specific regulation of foreign investment lay outside its scope. ${ }^{2}$ The National Policy strove to promote Canadian industry by limiting Canadian 
importation of foreign goods through punitive trade tariffs. ${ }^{3}$ However, many American companies avoided its application by selling domestically in Canada through subsidiaries, which were not subject to the tariffs. ${ }^{4}$ Accordingly, American foreign investment, chiefly through subsidiaries, continued to climb steadily from approximately \$15 million in 1870 to $\$ 160$ million in 1899.5 Stable Canadian banks, improvements in communications, and transportation, as well as the fact that Canada had never nationalized a foreign company, encouraged American foreign investment to continue. ${ }^{6}$ As a result, while relative rates of British investment decreased, American foreign investment as a proportion of total foreign investment in Canada rose from 13.6 percent in 1900 to 75.5 percent in $1950{ }^{7}$

\section{B. RAPID FOREIGN INVESTMENT POST-WORLD WAR II}

The 1950s and 1960s experienced markedly higher levels of American investment. Between the end of World War II and 1967, foreign direct investment in Canada "increased from $\$ 2$ billion to $\$ 17$ billion ... [and the number of takeovers] of Canadian firms increased from fewer than ninety-three firms in 1967 to 1,963 in 1968.” By the middle of the 1950s, the US was receiving 60 percent of Canadian exports and supplying 70 percent of Canadian imports. ${ }^{9}$ By the early 1970s, Americans held approximately 78 percent of total Canadian foreign investment, representing "more than [50 percent] of the Canadian manufacturing, mining, and smelting industries ... and nearly [100 percent] of the automobile, rubber, and aluminum industries." ${ }^{10}$ American foreign investment in Canada would eventually climb to 80 percent in 1980, representing $\$ 33$ billion. ${ }^{11}$

Oil and gas assets were no exception to the trend of increased American economic influence, as commentators note that the majority of the industry had come to be Americancontrolled by the late 1950s. ${ }^{12}$ By 1967, American ownership of the Canadian petroleum and natural gas sector had reached 60 percent, ${ }^{13}$ and by 1981, Canada's then six largest oil companies, namely Imperial Oil, Gulf Canada, Texaco Canada, Shell Oil, Amoco Canada, and Mobil Oil were all either majority-owned or wholly-owned by foreign entities (five by Americans). ${ }^{14}$

Susan D Romer, “Was the Sigh of Relief Premature? The Investment Canada Act” (1986) 19:3 Vand J Transnat'l L 613 at 614.

$4 \quad$ Charles Getman, “Canada’s National Energy Program: An Analysis” (1980) 3:1 Hous J Int’l L 155 at 155.

Ibid at 156.

Ibid.

Romer, supra note 3 at 615.

Thomas H Olson, "Foreign Investment Restrictions on Canadian Energy Resources" (1980) 14 Int'l Law 579 at 580 .

Getman, supra note 4 at 157.

Ibid at 162 .

Ibid.

Romer, supra note 3 at 615.

Herb Gray, Foreign Direct Investment in Canada (Ottawa: Information Canada, 1972) (Chair: Herb Gray).

Getman, supra note 4 at 162 . 


\section{A Movement TowARD Restrictive REgulation}

\section{A. Growing Hostility AND Economic NATIONALISM}

As a result of the concentrated foreign ownership and perceived Americanization of Canadian industry, Canadians began to view foreign economic influence more critically. Although Canadians arguably benefitted from higher standards of living that foreign investment created, fears began to arise about the risks of becoming a "branch plant" economy. Some economists began to suggest that multinational firms could have negative effects on the various domestic economies in which they operated. ${ }^{15}$ Commentators became suspicious that foreign firms would be reluctant to place Canadians in senior management positions in their Canadian operations, prefer foreign over Canadian suppliers, prevent Canadian subsidiaries from exporting because of conflicting sales mandates with other foreign affiliates, prevent Canadian affiliates from achieving efficient scale, would use internal transfer pricing to keep profits low and benefit from unfair tax treatment, and create barriers to entry for domestic competitors. ${ }^{16}$ Other concerns centred on employment levels in that multinational firms that experienced economic hardship would scale back subsidiary operations first, subjecting those economies to disproportionately high levels of employment risk. ${ }^{17}$ These concerns have not abated over time. Indeed, all of these concerns are echoed today in the nature of undertakings which Industry Canada typically seeks from foreign investors as a condition of approval of their investments under the ICA.

\section{B. GOVERNMENT SCRUTINY AND POLICY REPORTS}

The increased attention that American foreign investment was receiving was accompanied by the release of four government-sponsored reports: the 1957 Gordon Report, ${ }^{18}$ the 1968 Watkins Report, ${ }^{19}$ the 1970 Wahn Report, ${ }^{20}$ and most notably the 1972 Gray Report. ${ }^{21}$ At a general level, each of the reports consistently expressed concern over:

1. the amount of foreign investment in Canada,

2. the growth in the percentage of American investment compared to all foreign investment in Canada,

3. the concentration of the investment in key sectors,

4. the lack of investment opportunities for Canadians from Canadian savings, and

Russell Deigan, Investing in Canada: The Pursuit and Regulation of Foreign Investment (Scarborough: Thomson Professional Publishing Canada, 1991) at 2.

Ibid at 4.

Ibid.

Walter Gordon, Royal Commission on Canada's Economic Prospects, Final Report of the Royal Commission on Canada's Economic Prospects (Ottawa: Queen's Printer, 1958).

19

Melville Watkins, Task Force on the Structure of Canadian Industry, Foreign Ownership and the Structure of Canadian Industry - Report of the Task Force on the Structure of Canadian Industry, (Ottawa: Queen's Printer, 1968).

20 Ian Wahn, House of Commons, Standing Committee on External Affairs and National Defence, Eleventh Report of the Standing Committee on External Affairs and National Defence Respecting Canada-U.S. Relations (1970).

Gray, supra note 13 at 20-21. 
5. the implied political dependence of Canada upon the United States. ${ }^{22}$

More specifically, the Watkins Report expressed concern that a "potential shift outside the country of the locus of some types of decision-making" could result from foreign investment. $^{23}$ The Watkins report ultimately concluded that

[t]he major deficiency in Canadian policy has not been its liberality toward foreign investment per se but the absence of an integrated set of policies, partly with respect to foreign and domestic firms, partly with respect only to foreign firms, to ensure higher benefits and smaller costs for Canadians from the operations of multinational corporations. ${ }^{24}$

The Gray Report set out to build on the conclusions of the reports that came before it, in order to formulate a foreign investment policy that would

enable Canadians

(a) to exercise greater control over the national economic environment;

(b) to maximize the benefits and minimize the costs to Canada of foreign direct investment; and

(c) to retain and increase Canadian ownership of business activity where this is feasible or desirable for economic, social, cultural or other reasons. ${ }^{25}$

The Gray Report also expressed serious concern with the levels of American industry ownership in Canada. Consequently, it explored three basic avenues by which foreign investment could be regulated, along the following spectrum:

a) Discretionary approach: involved the creation of an administrative review process that could be conducted on a flexible, case-by-case basis. ${ }^{26}$

b) Moderate approach: included a "key sector” approach, whereby legislation affecting certain industries would be amended to provide bright line safeguards. ${ }^{27}$ This approach had already been instituted to a more limited degree in earlier years. For example, one of the first sectors to receive particular legislative attention during the rise of American foreign ownership was the financial services industry. ${ }^{28}$ Various amendments implementing requirements for the nationality of directors and nationality of share ownership were applied to legislation such as the Bank Act, ${ }^{29}$ the Canadian and British Insurance Companies Act, ${ }^{30}$ the Loan Companies Act, ${ }^{31}$

Getman, supra note 4 at 157.

Watkins, supra note 19 at 27.

Ibid at 392.

Gray, supra note 13 at 9 .

Olson, supra note 8 at 581.

Ibid.

M Jacqueline Sheppard \& Mungo Hardwicke-Brown, “Overview of the Investment Canada Act with a Focus on Investments in Canada's Upstream Oil and Gas Industry” (1992) 30:1 Alta L Rev 4 at 6. SC 1991, c 46.

SC 1991, c 47; 1958 (UK), 6 \& 7 Eliz 2, c 72.

RSC 1927, с 28. 
and the Trust Companies Act. ${ }^{32}$ Further targeted amendments were introduced to provincial and federal legislation that regulated "sensitive" industries, including "newspapers, broadcasting, transportation, securities, and oil and gas." 33

c) Restrictive approach: consisted of mandatory Canadian ownership levels for firms of certain sizes across all industries. ${ }^{34}$

Ultimately, the discretionary administrative "review" approach would form the basis of the Foreign Investment Review Act, ${ }^{35}$ discussed below.

\section{THE ForeIgN INVESTMENT REVIEW ACT}

Although foreign investment in Canadian industry was, to some extent, affected by various government initiatives and limited sector regulation, it remained largely unrestricted. The 1973 introduction of the FIR Act was Canada's first comprehensive foreign investment statute, and marked a sharp departure from the largely "hands off” approach enjoyed by foreign investors in prior years. The legislation required foreign investors to submit applications to the Foreign Investment Review Agency (FIRA) for an acquisition of control of a Canadian business or the establishment of a new Canadian business that was unrelated to an existing business. ${ }^{36}$ In a major concession, the FIR Act did not inhibit the largest source of foreign investment - existing foreign investors in Canada from expanding their existing business into a related area. ${ }^{37}$

The FIRA was not a final decision-maker on applications for review. Instead, its role was to evaluate the proposed transaction and forward a recommendation to the Governor in Council, essentially the federal cabinet. ${ }^{38}$ In order to receive approval from the FIRA, an investor had to demonstrate that the investment would be of "significant" benefit to Canada. ${ }^{39}$

The FIR Act was enforced according to which government was in power. For example, in the early days of enforcement under the Liberal government of Prime Minister Trudeau, out of the 50 cases that were resolved in 1974, 34 percent were either disallowed or withdrawn. ${ }^{40}$ Out of the 164 cases reviewed in 1975, a further 29 percent were disallowed

RSC 1970, T-16.

Sheppard \& Hardwicke-Brown, supra note 28 at 6. See also Olson, supra note 8 at 598-601 for a discussion of regulation of energy resource development in the territories. The Canada Oil and Gas Regulations, CRC, c 1518 implemented under the Territorial Lands Act, RSC 1985, c T-7 and the Federal Real Property and Federal Immovables Act, SC 1991, c 50 required that oil and gas leases be granted only to Canadian citizens or corporations with certain levels of Canadian ownership or a listing on a Canadian stock exchange. Notably, the impact of these regulations was limited to the Canadian territories, and (at the time) "has not had an extreme effect on foreign investment in energy resources because most of the energy resource development has been in Alberta” (Olson, ibid at 600). Additionally, the Northern Mineral Exploration Assistance Regulations, CRC, с 332 discriminated against foreign holders of oil and gas leases in Northern Canada for the purposes of providing financial assistance.

Olson, ibid at 581.

SC 1973-74, c 46 [FIR Act].

Sheppard \& Hardwicke-Brown, supra note 28 at 8.

Deigan, supra note 15 at 5.

Ibid.

Ibid at 4.

Getman, supra note 4 at 160 . 
or withdrawn. ${ }^{41}$ However, only 3.1 percent of all cases were disallowed by 1983 , and in the nine months leading up to the repeal of the FIR Act in 1985, under the new Progressive Conservative government led by Prime Minister Mulroney, no cases were disallowed. ${ }^{42}$

Oil and gas transactions fared somewhat better under the FIRA regime, as they tended to provide benefits relating to increased employment and capital injection into the Canadian economy, as well as the increased use of Canadian parts and services to support increased levels of resource processing. ${ }^{43}$ Out of the 57 applications relating to the acquisition of oil and gas industry that had been reviewed prior to 8 April 1980, only 14 percent were rejected. ${ }^{44}$

Predictably, the FIR Act's imposition on what was once a largely unrestricted practice generated resentment. The review process itself attracted several criticisms, including:

[T]he extended delays in processing notices (in some instances in excess of one year), particularly for large or politically sensitive investments and the attendant costs of lost opportunity and actual expenditure; the commitments sought by the [FIRA], frequently at the request of the Minister, which were considered by some to be unreasonable and lacking in appreciation of commercial reality; the failure of the [FIRA] to recognize good corporate citizenship and previous experience in assessing subsequent notices; the lack of communication in the process attributable to there being no specific criteria for securing allowance and no reasons given for disallowance; and the lack of opportunity to respond to the input of federal and provincial governments and third party intervenors. ${ }^{45}$

Given that the FIR Act applied to the establishment of new Canadian businesses, it had the potential to capture very small entrepreneurial ventures, which many argued was unduly burdensome to small investors and an ineffective use of the FIRA's resources. ${ }^{46}$

\section{The National Energy Program}

The Trudeau government's introduction of the National Energy Program (NEP) on 28 October $1980^{47}$ arguably had a much more profound impact on foreign ownership in the Canadian energy industry than the FIR Act. The NEP stemmed from the government's position "that the oil and gas sector was a unique case and that special measures, not required in other sectors were needed to ensure more Canadian control." ${ }^{48}$ More specifically, the NEP sought to increase ownership in the Canadian oil and gas industry from approximately 25 percent to 50 percent by $1990 .^{49}$

The NEP was implemented through a series of federal regulations which sought to inhibit the expansion of foreign ownership in the oil and gas sector in three key ways. The first was

Ibid.

Deigan, supra note 15 at 6.

Olson, supra note 8 at 596.

Ibid at 609.

W Brian Rose, “Foreign Investment in Canada: The New Investment Canada Act” (1986) 20:1 Int'l Law 19 at 21-22.

Deigan, supra note 15 at 5-6.

Sheppard \& Hardwicke-Brown, supra note 28 at 9.

Ibid at 10.

Getman, supra note 4 at 165 . 
by gradually reducing income deductions for depletion allowances as a result of the exhaustion of oil assets, which could account for reductions in taxable income as high as 33 percent. ${ }^{50}$ Although the elimination of depletion allowances applied to all oil and gas companies regardless of ownership nationality, it was replaced by exploration grants that were 10 percent for companies with at least 50 percent Canadian ownership..$^{51}$ The net effect of the substitution of policies was that Canadian-controlled companies had significantly lower after-tax exploration costs, in some cases less than a third of what foreign companies had to pay. ${ }^{52}$ The second aspect of the NEP was the institution of a bright line requirement that mandated "a minimum 50 percent Canadian ownership ... to produce any energy from any new discoveries in the Canada Lands. ${ }^{, 53}$ As a result, foreign oil companies had to change their ownership structures to carry on any further exploration activities. ${ }^{54}$ The third notable feature of the NEP was the Crown's right to claim 25 percent of oil discovered on Crown lands. ${ }^{55}$ These so-called "back-in provisions" were viewed by some to be tantamount to "retroactive confiscation" in favour of the Canadian government. ${ }^{56}$

Furthermore, the NEP directed FIRA "to block any attempts by foreign oil companies to take over Canadian enterprises, while at the same time it exposed foreign oil companies to massive takeover attempts by Canadian capital. ${ }^{, 57}$ The NEP specifically referenced FIRA, "entrusting" it to prevent the increase of foreign energy production. ${ }^{58}$

\section{E. The Creation of Petro-Canada AND ALBERTA ENERGY COMPANY}

Roughly contemporaneous with the FIR Act, and as a mechanism to address high foreign ownership in the oil and gas sector, the Liberal government created Petro-Canada, a Crown corporation, in $1975 .^{59}$ To many observers, the formation of Petro-Canada was an initiative by the government to nationalize the energy industry through gradual acquisitions of foreign ownership interests through a SOE. These acquisitions were facilitated by the NEP, which encouraged sale of foreign ownership to Petro-Canada by those who found the NEP's provisions too burdensome to effectively compete. ${ }^{60}$

Petro-Canada made many significant acquisitions of foreign ownership interests, including the purchase of US-based Atlantic Richfield Canada for CDN\$342 million in 1976, Belgium-based Petro-Fina for approximately US\$1.5 billion in 1981, and UK-based BP Canada for US\$348 million in $1983 .{ }^{61}$ Notably, Petro-Canada engaged in heavy borrowing to effect these acquisitions, much of which came from American financial institutions. As

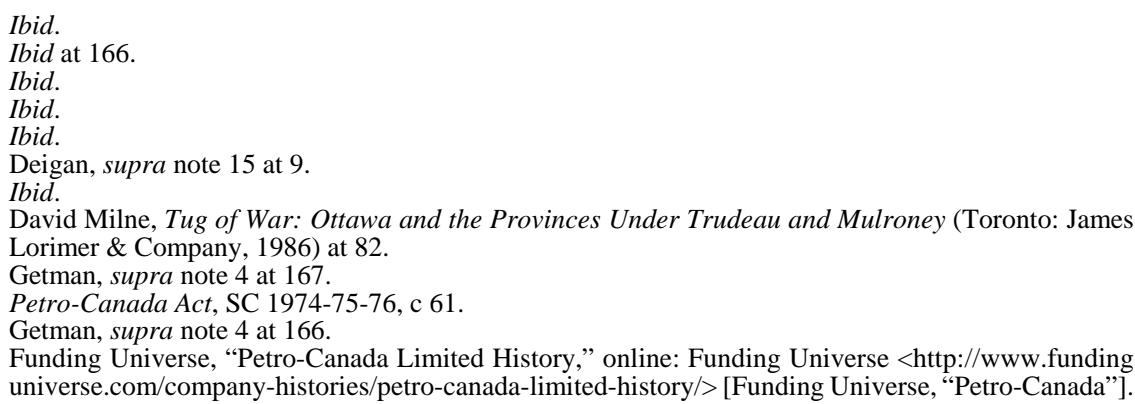
universe.com/company-histories/petro-canada-limited-history/> [Funding Universe, "Petro-Canada"]. 
a result, some questioned whether substituting foreign ownership for foreign debt was an artificial and ultimately ineffective form of nationalization. ${ }^{62}$

Owing largely to the combined effect of the NEP and the creation of Petro-Canada, "Canadian ownership of upstream production revenues increased from 28 percent to 40 percent” in the four years following the NEP's implementation. ${ }^{63}$ By the mid-1980s, PetroCanada had grown to become Canada's “third-largest gasoline marketer and the only nationwide station chain." ${ }^{64}$ Foreign industry participants claimed that favourable treatment conferred upon Petro-Canada and other Canadian companies was simply discriminatory, and that the "policy doesn't just push foreign owners out, it shoves them.",65

At the provincial level, the "Alberta government enacted the Petroleum Marketing Act ${ }^{66}$ in 1973, which created the 'Petroleum Marketing Commission'” to, among other things, market petroleum produced in Alberta. During this time the provincial government sought to reduce dependence on foreign oil companies and in 1974 created Alberta Energy Company Ltd. (AEC). The ownership of AEC was divided equally between the provincial government and private citizens. Through AEC, certain revenues from the marketing operations of the Petroleum Marketing Commission were used to acquire significant holdings in resource properties, primarily within the province. ${ }^{67}$ Although the Alberta government sold its remaining ownership interest in AEC in 1993, the impact of the government's capital investment program was evident. By the mid-1990s AEC had grown to be the second largest publicly-traded oil and gas exploration company on the Canadian stock exchange. ${ }^{68}$

\section{Progressive Return to Liberalization}

\section{A. DEPARTURE OF THE FoREIGN INVESTMENT REVIEW ACT AND THE NATIONAL ENERgy PRogram AND THE INTRODUCTION OF THE INVESTMENT CANADA ACT}

The strong criticisms of the FIR Act and NEP, a recession in the Canadian economy during the early 1980s, and a shift in economic ideology towards accepting the benefits of private sector investment (exemplified by Margaret Thatcher's privatization policy in the UK in the early 1980s) eventually began to erode the nationalistic sentiments that laid the foundation of the restrictive policy stance on foreign investment. ${ }^{69}$ As a result, a return to a more liberal approach that encouraged foreign investment began to regain popularity. In 1984, Brian Mulroney's Progressive Conservative party included a more liberalized foreign investment policy in its campaign platform, and as one of its first acts after coming into

Getman, supra note 4 at 166-67, n 62 (stating that "[t]he previous purchases of Atlantic Richfield Canada and Pacific Petroleum by Petro-Canada were financed by foreign loans, principally from the United States”).

Sheppard \& Hardwicke-Brown, supra note 28 at 11.

Funding Universe, "Petro-Canada,” supra note 61.

Getman, supra note 4 at 165.

SA 1973, c 96. See also Morris C Shumiatcher, “Canada’s Constitutional Curmudgeons, or a Tale of Three Cities” (1975) 21 McGill LJ 113 at 118.

Ibid at 118.

Funding Universe, “Alberta Energy Company Ltd History,” online: Funding Universe <http://www. fundinguniverse.com/company-histories/alberta-energy-company-ltd-history/> [Funding Universe,

“Alberta Energy”].

Rose, supra note 45 at 21. 
power, it replaced the FIR Act with the ICA on 30 June $1985 .^{70}$ The Mulroney government also signed the Western Accord on 28 March 1985, which phased out the key elements of the NEP, ${ }^{71}$ and the government began to privatize Petro-Canada in February of $1990 .^{72}$ Notably, however, a residual form of Canadian control in the petroleum sector would persist. Upon the amalgamation of Suncor Energy Inc. and Petro-Canada in 2009, the statutory ownership restrictions applicable to Petro-Canada, which prevented it from being taken over, were inherited by Suncor. ${ }^{73}$ In this respect, although the restrictions do not expressly prohibit foreign ownership and control, they effectively continue to prevent any person, domestic or foreign, from acquiring control of one of Canada's largest Canadian-controlled oil and gas companies, without the express approval of Parliament.

Since 1985, the ICA has been amended on numerous occasions to take into account the progressive liberalization of Canada's foreign investment regime as a result of Canada's free trade obligations. In its current form, the ICA differs from the FIR Act in a number of important respects. Approval is based upon whether the proposed benefit satisfies a lower threshold of "net benefit" instead of "significant benefit."74 The Minister of Industry (the Minister) is responsible for decision-making instead of both an administrative agency and the federal cabinet. ${ }^{75}$ Furthermore, the ICA limits the scope of the review so that only direct acquisitions of control of Canadian businesses with a book value of assets above a large financial threshold (other than for cultural businesses or transactions involving both buyers and sellers that are not controlled by nationals of World Trade Organization (WTO) members), are subject to pre-closing review. ${ }^{76}$ To address concerns about the delays and

Sheppard \& Hardwicke-Brown, supra note 28 at 13.

Tammy Nemeth, "Pat Carney and the Dismantling of the National Energy Program" (1998) 7 Past Imperfect 87 at 104-105.

Funding Universe, "Petro-Canada,” supra note 61.

See Suncor Energy Inc, “Annual Information Form Dated March 1, 2013,” online: Suncor <http://www. suncor.com/pdf/Suncor_AIF_2013_en.pdf > at 71:

The Petro-Canada Public Participation Act requires that the Articles of Suncor include certain restrictions on the ownership and voting of voting shares of the company. The common shares of Suncor are voting shares. No person, together with associates of that person, may subscribe for, have transferred to that person, hold, beneficially own or control otherwise than by way of security only, or vote in the aggregate, voting shares of Suncor to which are attached more than 20 percent of the votes attached to all outstanding voting shares of Suncor ... Suncor's Articles, as required by the Petro-Canada Public Participation Act, also include provisions requiring Suncor to maintain its head office in Calgary, Alberta; prohibiting Suncor from selling, transferring or otherwise disposing of all or substantially all of its assets in one transaction, or several related transactions, to any one person or group of associated persons, or to non-residents, other than by way of security only in connection with the financing of Suncor.

ICA, supra note 1 , s 16.

Sheppard \& Hardwicke-Brown, supra note 28 at 15 . However, the process of review is initially conducted by the Investment Review Division of Industry Canada (IRD) which recommends approval or rejection of an investment to the Minister. Approvals of significant investments are understood to involve cabinet consideration (see ICA, ibid, ss 4-6).

ICA, ibid, ss $14,14.1$. Initially under the ICA, the review threshold for a direct acquisition was only $\$ 5$ million, and for an indirect acquisition, where the corporation acquired was incorporated outside of Canada but in turn held a Canadian subsidiary, was \$50 million. However, as a result of the landmark Canada-US Free Trade Agreement, the review thresholds were changed to \$25 million and \$100 million, respectively, in 1989. By 1992, the review threshold for direct transactions was increased to $\$ 150$ million and thereafter increased in accordance with a statutory formula based on the change in Canada's GDP. The direct threshold in 2013 has increased to \$344 million. By 1992, an indirect transaction involving a US investor was not reviewable unless the Canadian assets represented over 50 percent of the worldwide assets being acquired. As a result of Canada's WTO commitments, the higher thresholds enjoyed by US investors were extended in the mid-1990s to all investors controlled by WTO nationals. The 50 percent requirement for indirect transactions was dropped, so that now virtually all indirect transactions (outside of culture) are no longer reviewable. See generally Deigan, supra note 15 at 37-38, 163-64. 
timing uncertainty inherent in the FIR Act process, the ICA also introduced statutory review timelines under which the Minister's initial review period is 45 days, with the ability to impose a 30-day extension upon giving notice to the investor. ${ }^{77}$ Another significant difference from the FIR Act is the concept of “deemed approval," whereby the ICA considers transactions to be automatically approved if the review timeline expires without any extension or express disapproval from the Minister. ${ }^{78}$

The ICA was accompanied by guidance from Industry Canada that enabled investors to determine if their activity might trigger the application of the ICA. In the energy sector, properties "upon which only exploration for oil or gas has been conducted" were not considered to be "businesses" and, therefore, are not subject to the application of the ICA. ${ }^{79}$ Additionally, a property must either have commenced actual production, or contain economically recoverable quantities of oil or gas and be the subject of drilling to recover the reserves, in order to be classified as a "business." ${ }^{\text {"80 }}$ The government also released summaries of 52 opinions that were provided under the ICA during the initial months after the ICA came into force. ${ }^{81}$ Furthermore, the government published an annual report up until 1992-93 ${ }^{82}$ and occasionally issued news releases concerning approvals of the more significant cases until the early 2000s. These transparency mechanisms afforded investors some insight into how the ICA was being applied and the nature of the undertakings that could be expected in order to secure approval.

\section{B. Discontinuation of the Masse Policy}

Despite the repeal of the FIR Act and the NEP, a major foreign investment restriction lingered on in the oil and gas industry. The so-called "Masse Policy" (formally known as the "Oil and Gas Acquisitions Policy") was implemented in connection with the Canada-United States Free Trade Agreement, such that foreign acquisitions of "financially healthy" Canadian-controlled upstream oil and gas businesses with assets of at least $\$ 5$ million would be disallowed. ${ }^{83}$ Acquisitions of these businesses would only be permitted where the business was in "clear financial difficulty," along with negotiations to extract undertakings from the investor sufficient to demonstrate "net benefit." ${ }^{44}$ Acquisitions of foreign-controlled businesses were permitted.

Industry Canada, "An Overview of the Investment Canada Act (FAQs),” online: Industry Canada $<$ http://www.ic.gc.ca/eic/site/ica-lic.nsf/eng/h_lk00007.html>. Further extensions are possible with the consent of the investor (see ICA, supra note 1, ss 21-22).

$78 \quad$ ICA, ibid, ss 21(9), 22(4).

79 Industry Canada, "Interpretation Note No. 4 - Business," online: Industry Canada <http://www.ic.gc.ca/ eic/site/ica-lic.nsf/eng/lk00051.html\#p4> [“Interpretation Note 4”].

80 Ibid.

81 See Peter R Hayden, Foreign Investment in Canada: A Guide to the Law, loose-leaf (consulted on 12 March 2013), (Toronto: Carswell, 2009), vol 4 at para 4,000 ff (reprinting the original opinion summaries). The summaries are still the only such guidance available.

82 This practice was revived for 2009-10 as a result of amendments to the ICA in 2009 (see Industry Canada, Investment Canada Act: Annual Report 2009-2010, (Ottawa: Industry Canada, 2010) at 1 [ICA Annual Report]).

83 Exchange of letters between The Hon James A Baker, III, Secretary of the Treasury of the United States and The Hon Michael H Wilson, Minister of Finance of Canada, 12 May 1988 and 16 May 1988.

84 Energy, Mines and Resources Canada, Press Release \& Backgrounder, "Epp Announces Changes to Foreign Investment Policy for Canadian Oil and Gas Industry” (25 March 1992) [EMRC Update]. 
As a result of the Masse Policy, various structuring alternatives were developed in order to comply with the policy but at the same time achieve the economic equivalent of an acquisition. For example, British Gas plc acquired just under one-third of the voting shares of Bow Valley Industries Ltd. (so as to fall beneath the one-third deemed acquisition of control rule) and preferred shares which conferred a 51 percent equity stake on a fully-diluted basis. In another transaction, the acquisition of control of 43 percent of Husky Oil Ltd. by Li Ka-Shing of Hong Kong was not considered to be an acquisition of control because the balance of the shares was held by his son (a Canadian under the ICA) and a Canadian corporation, Nova Corp. ${ }^{85}$

By 1992, it was apparent that Canadian ownership in the oil and gas industry likely exceeded the 50 percent target established under the NEP. ${ }^{86}$ On 25 March 1992, the Masse Policy was eliminated, and as a result, the threshold for US investments jumped to $\$ 150$ million. ${ }^{87}$ This figure was indexed, to progressively increase over time to the $\$ 344$ million threshold that exists today and is applicable to all WTO investors.

\section{TRENDS AND DEVELOPMENTS FROM THE LATE 1990S TO MID-2000S}

Enabled by the relatively low value of the Canadian dollar, Canada experienced a "merger wave" from the mid-1990s to mid-2000s that resulted in significant increases in foreign direct investment. Foreign direct investment into Canada totalled CDN\$9.6 billion in 1996, and climbed as high as CDN\$66.8 billion in 2000 and CDN\$108.4 billion in $2007 .^{88}$

Notable acquisitions in the resource sector included Brazil-based Vale's 2006 acquisition of Inco Ltd., the world's second largest nickel mining company for CDN\$19.4 billion, ${ }^{89}$ France-based Arcelor SA's acquisition of steelmaker Dofasco for CDN\$5.6 billion, ${ }^{90} \mathrm{UK}-$ based Rio Tinto's US\$38 billion acquisition of Alcan Inc. in 2007, ${ }^{11}$ and US Steel's US\$1.2 billion acquisition of Stelco in 2007. ${ }^{92}$ All of these acquisitions were approved under the ICA. The terms of approval typically were not made public. Coupled with allegations that the investors had not lived up to their undertakings, there was a growing chorus of public discomfort with the speed and scale of the so-called "hollowing out" of Canadian control of

\footnotetext{
85 See Harry S Campbell, “Investment Canada and the Canadian Oil and Gas Industry” [1990] 9 OGLTR 299 at 302.

EMRC Update, supra note 84.

Ibid.

ICA Annual Report, supra note 82 at 15.

Adriana Brasileiro \& Heloiza Canassa, "Vale Buys Control of Canadian Nickel Miner Inco,” online: Bloomberg <http://www.bloomberg.com/apps/news/2006-10-24/vale-buys-control-of-canadian-nickelminer-inco-update4-.html $>$.

90 "Dofasco and Arcelor announce signature of support agreement for Arcelor’s C\$71.00 all-cash offer," online: The Free Library <http://www.thefreelibrary.com/Dofasco+and+Arcelor+announce+signature+ of+support+agreement+for...-a0141198898>.

91 "Rio Tinto pays a steep price for Alcan purchase," online: The Northern Miner < http://www.northern miner.com/news/rio-tinto-pays-a-steep-price-for-alcan-purchase/1002015430/>.

92 "United States Steel Corporation Completes Acquisition of Stelco Inc.," online: US Steel < http://www. ussteel.com/uss/portal/home/newsroom/pressreleases>; see generally Laura Bobak, "U.S. Steel to buy Stelco,” online: Toronto Star <http://www.thestar.com/business/2007/08/27/us_steel_to_buy_stelco. html>.
} 
iconic Canadian companies. ${ }^{93}$ Examples of notable acquisitions of Canadian oil and gas businesses during this period, most of which involved foreign parties, include:

- Conoco Inc.’s purchase of Gulf Canada Resources Limited for CDN\$9.8 billion $(2001) ;^{94}$

- $\quad$ Burlington Resources Inc.’s CDN\$3.3 billion acquisition of Canadian Hunter Explorations (2001); ${ }^{95}$

- Devon Energy Corporation’s CDN\$7.2 billion acquisition of Anderson Exploration Ltd. (2001); ${ }^{96}$

- Calpine Corporation’s CDN\$1.8 billion acquisition of Encal Energy Ltd. (2001); $;^{97}$

- Duke Energy’s US\$8 billion acquisition of Westcoast Energy Inc. (2002); ${ }^{98}$

- $\quad$ BG Group’s US\$345.6 million acquisition of El Paso Oil and Gas Canada, Inc. from El Paso Corporation (2004); ${ }^{99}$

- $\quad$ Enerplus Resources Fund's and Acclaim Energy Trust's CDN\$1.09 billion acquisition of mature assets in Western Canada through an interest in the Chevron Canada Resources (Western) Partnership (2004); ${ }^{100}$

- US-based Kinder Morgan’s acquisition of pipeline company Terasen Inc. for CDN\$6.9 billion (2005);

Eric Reguly, "The head-office exodus,” online: The Globe and Mail <http://www.theglobeandmail. com/report-on-business/rob-magazine/top-1000/the-head-office-exodus/article4249283/>. Ten years ago, Royal Bank of Canada CEO Gord Nixon gave a speech where he "lamented the loss of big-name companies through mergers and acquisitions, noting that in the previous two years alone (2000-2002), some 62 of the country's largest corporate players had disappeared, more than half of them through foreign takeovers" (ibid).

“Conoco Acquires Gulf for \$9.8B," online: Lexpert <http://www.lexpert.ca/deal.php?id=569>; Alexei Barrionuevo \& Tamsin Carlisle, "Conoco Reaches Deal to Buy Gulf Canada for \$4.33 Billion,” online: Wall Street Journal <http://online.wsj.com/article/SB991135317583560130.html>. “Canadian Hunter bought by Burlington Resources for \$3.3 billion," online: CBC News <http://www. cbc.ca/news/business/canadian-hunter-bought-by-burlington-resources-for-3-3-billion-1.256986>. Devon, "Devon Energy to Acquire Anderson Exploration and Become North America's Largest Independent Producer of Oil and Natural Gas," online: Devon <http://www.dvn.com/NEWSROOM/ Pages/NewRelease.aspx?id=203875\#terms?disclaimer=yes>; "Devon Energy Acquires Anderson Exploration for \$7.2B," online: Lexpert <http://www.lexpert.ca/deal.php?id=88>; Gary Park, "Devon Energy expands U.S. control of Canada's Arctic," online: Petroleum News <http://www.petroleum news.com/pn truncate/574746147.shtml>.

“Calpine Corporation Acquires Encal Energy,” online: Lexpert <http://www.lexpert.ca/ magazine/bigreal-estate-deals/calpine-corporation-acquires-encal-energy-612/>; "Encal and [Calpine] enter C\$1.8 billion merger," online: Hydrocarbon Online <http://www.hydro carbononline.com/doc/Encal-andClagary-enter-C18-billion-merger-0001>.

Duke Energy, "Duke Energy Completes $\$ 8$ billion Acquisition of Westcoast Energy,” online: Duke Energy <http://www.duke-energy.com/news/releases/2002/Mar/2002031401.html>. BG Group, “BG Group to Acquire El Paso Oil and Gas Canada, Inc. for US \$345.6m,” online: BG Group <http://www.bg-group.com/MediaCentre/PressArchive/2004/Pages/021604-sx.aspx>.

"Enerplus and Acclaim Acquire Interest in Chevron Canada Resources (Western)," online: Lexpert $<$ http://www.lexpert.ca/magazine/big-real-estate-deals/enerplus-and-acclaim-acquire-interest-inchevron-canada-resources-western-2367/>. 
- $\quad$ ConocoPhillips’ US\$35.6 billion acquisition of Burlington Resources Inc. (2006); ${ }^{102}$ and

- $\quad$ Canadian Natural Resources Limited’s US\$4.1 billion acquisition of Anadarko Canada Corporation from Anadarko Petroleum Corporation (2006). ${ }^{103}$

Investment during this period still almost exclusively originated from the private sector. However, in 2004 China Minmetals Corp. proposed to acquire Noranda Inc. which owned 59 percent of leading Canadian nickel producer Falconbridge Limited. Although the transaction did not proceed, concerns about Minmetals' human rights record generated controversy about the proposal. ${ }^{104}$ Soon afterwards, the government expressed a concern about the potential negative impact of SOE investment by stating that "foreign investment by large state-owned enterprises with non-commercial objectives and unclear corporate governance and reporting may not be beneficial to Canadians.”105

\section{THE WILSON REPORT: 2008}

As a result of the Advantage Canada study and the 2007 Budget, Prime Minister Harper's new government sought the advice of a distinguished panel informed by public consultations on the subject of Canada's competition policies and its framework for foreign investment policy. ${ }^{106}$ On 26 June 2008, the Competition Policy Review Panel submitted a comprehensive report to the Canadian Government entitled Compete to Win. ${ }^{107}$ The Panel reported the concerns over foreign investment and, primarily, the "hollowing out” of Canadian businesses and stated:

We heard concern that Canadian businesses are being swallowed by foreign competitors in an era of global consolidation. The recent increase in foreign direct investment (FDI) in Canada, particularly through mergers and acquisitions (M\&As), has raised concerns in many quarters about diminished control and influence by Canadians over the domestic economy. As multinational enterprises have consolidated, foreign investors have acquired a number of well-established Canadian companies, including Alcan, Falconbridge, Inco and Hudson's Bay Company. Such firms have been significant employers and anchors of Canadian communities. These transactions sparked questions regarding Canada's foreign investment policies as well as about the effect of losing corporate head offices and associated high-value jobs and services. The transactions have also highlighted the global nature of industry restructuring. ${ }^{108}$

"Energy smolik faces challenges as big as texas," online: Canada.com <http://www.canada.com/ story.html?id=1e54dff5-b69c-4aee-859b-b8ac968d6d0a>; "ConocoPhillips to Buy Burlington Resources for \$35.6 Bln,” online: Bloomberg Businessweek <http://www.businessweek.com/stories/ 2005-1212/conocophillips-to-buy-burlington-resources-for-35-dot-6-bln>. Canadian Natural, "Canadian Natural Resources Limited Completes Acquisition of Anadarko Canada Corporation,” online: Canadian Natural Resources Limited <http://www.cnrl.com/upload/media_ element/146/01/1102acc_approval.pdf>. Aaron A Dhir, "Of Takeovers, Foreign Investment and Human Rights: Unpacking the NorandaMinmetals Conundrum” (2006) 22:1 BFLR 77. Department of Finance Canada, Advantage Canada: Building a Strong Economy for Canadians (Ottawa: Department of Finance, 2006) at 87.

Competition Policy Review Panel, “Terms of Reference,” online: Industry Canada <http://www.ic.gc.ca/ eic/site/cprp-gepmc.nsf/eng/h_00004.html>.

Competition Policy Review Panel, Compete to Win: Final Report - June 2008 (Ottawa: Public Works and Government Services Canada, 2008). Ibid at 15 . 
At the same time, the report noted that "overall, the data indicate that the share of assets in Canada’s non-financial industries under foreign control has not changed noticeably in recent years." ${ }^{109}$ Further, the report noted that Canadian companies were increasingly active in investing abroad and that Canada's share of worldwide foreign direct investment was decreasing substantially. The report rejected the contention that the ICA had had a chilling effect on foreign investment. It stated:

Of the over 1500 non-culture sector reviews undertaken by the Minister of Industry under the ICA since 1985, only one proposal has been disallowed.... [W]hen the actual practices regarding foreign investment are taken into account, the impact of Canadian government intervention is not materially different from that of other industrialized countries. ${ }^{110}$

The report made several recommendations that would "make Canada more competitive."111 The report recommended an increase to the ICA's review thresholds from (at the time) \$295 million to \$1 billion in enterprise value (noting that enterprise value "better reflects the increasing importance to our modern economy of service and knowledge-based industries in which much of the value of an enterprise is not recorded on its balance sheet”112), on the basis that foreign investment is beneficial to Canada absent exceptional circumstances and that the government should accordingly have a narrower power of intervention. $^{113}$

The report also suggested a major change to the "net benefit" determination, which would shift the onus from an investor having to demonstrate that a transaction would be of "net benefit" to Canada, to the Minister, who would have to show that an investment was "contrary to Canada's national interest."114 In the panel's view, such a change would extinguish perceptions that the Canadian government discourages foreign investment. ${ }^{115}$

The panel also pushed for increased transparency under the ICA, by requiring the Minister to provide public reasons for the disallowance of any transaction, instituting mandatory annual reports, and increasing the publication of interpretative guidelines. ${ }^{116}$

At the time of writing, the government has adopted the panel's recommendations regarding increased thresholds (which are not yet in force) and has to some extent increased transparency of enforcement of the ICA, but rejected its proposal to revise the "net benefit" test. $^{117}$

Ibid.

Ibid at 29

Ibid at 30 .

Ibid at 31.

Ibid.

Ibid at 32

Ibid.

Ibid at 32-33.

ICA, supra note 1 , s 16. 


\section{RECENT DEVELOPMENTS: New Questions and Potential Challenges}

The Compete to Win report was issued in June 2008, just before major, surprising developments in the enforcement of the ICA. In the just over four years which followed the report, the government:

- $\quad$ obtained statutory jurisdiction to review a broad range of investments on national security grounds in 2009; ${ }^{118}$

- $\quad$ brought court proceedings to enforce undertakings against US Steel in 2009 (now resolved); ${ }^{119}$

- $\quad$ turned down two major investment proposals (BHP/Potash in 2010 and Petronas/Progress Energy in 2012, though the latter was later approved); ${ }^{120}$

- $\quad$ announced new policies in late 2012 to permit a SOE to acquire control of an oil sands business on an exceptional basis only, and put all future SOE investments on a "watch list"; ${ }^{121}$ and

- $\quad$ amended the ICA in June 2013, to expand the definition of SOE and allow for Ministerial determinations as to whether an entity is controlled by a SOE or whether there has been an acquisition of control by a SOE, and permit significant extensions of the periods for national security review. ${ }^{122}$

In the context of the previously unopposed boom in foreign investment which occurred just prior to these developments and the more liberal policy position evidenced in the Compete to Win report, few if any foreign investors and their advisors anticipated a return to more interventionist foreign investment policies with the potential to actually derail their investment proposals. The remainder of this paper surveys the five developments, reviews the potential impact of planned new review thresholds, and sets out transaction planning considerations.

\section{A. National SEcurity Considerations}

In 2009, the ICA was amended to add a national security review framework under Part IV.1. ${ }^{123}$ The new provisions allow the Canadian government to review, prohibit, or impose conditions on a broad range of investments by non-Canadians irrespective of whether they satisfy the financial thresholds for review under the ICA. In addition to notifiable and reviewable investments, review on national security grounds can apply to any investment by

\footnotetext{
118 Ibid, part IV.1.

See below notes 152-55.

Further discussion of these cases can be found at pages 364-66 and 369-75.

For further discussion, see pages 369-75.

Bill C-60, An Act to implement certain provisions of the budget tabled in Parliament on March 21, 2013 and other measures, 1st Sess, 41st Parl, 2013, cl 136-45 (assented to on 26 June 2013) [Bill C-60]. For further discussion, see pages_360, 372 and 374-75. 
a non-Canadian, whether implemented or proposed, to "acquire, in whole or in part, or to establish an entity carrying on all or any part of its operations in Canada if the entity has (i) a place of operations in Canada, (ii) an individual or individuals in Canada who are employed or self-employed in connection with the entity's operations, or (iii) assets in Canada used in carrying on the entity's operations.” ${ }^{124}$ The scope of the provisions is considerably broader than the scope of the other review provisions of the ICA. Notably, the amendments capture an investment in an entity that would not otherwise have a sufficient base of operations in Canada to be considered a "Canadian business" which is a precondition for the ICA to apply for other purposes. There is no "safe harbour" ownership threshold for foreign investors, so that even very small investments which do not amount to an acquisition of control may be captured. The test applied is whether an investment is "injurious to national security."125 To date, the government has not issued any guidelines to assist investors in understanding whether their investments may be "injurious to national security"; the phrase itself is not defined in the ICA.

The timelines under the national security review process are lengthy. Currently, a review may consume over 130 days. This period will likely become further protracted under pending amendments which will extend certain periods and permit extensions where agreed between the Minister and foreign investor. ${ }^{126}$ Reviews under this process are ultimately conducted by the Governor in Council. ${ }^{127}$ At the first stage in the review process, the Minister may send a notice to the investor that a review of the investment may be ordered. ${ }^{128}$ If notice is sent prior to closing, the non-Canadian receiving the notice may not close the transaction until the issue is resolved. ${ }^{129}$ The Minister may require the investor to provide any information he or she considers necessary. ${ }^{130}$ The Minister must then either inform the investor that no review will be conducted or make a recommendation to the Governor in Council for review after consulting with the Minister of Public Safety. ${ }^{131}$

Upon having an investment referred to it by the Minister, the Governor in Council may "take any measures in respect of the investment that the Governor in Council considers advisable to protect national security." ${ }^{\prime 32}$ This can include ordering the non-Canadian not to implement the investment, authorizing the investment subject to the non-Canadian providing undertakings, or agreeing to terms set out by the Governor in Council. ${ }^{133}$ If the investment has already been implemented, the Governor in Council may order the non-Canadian to divest itself of control of the Canadian business or of its investment. ${ }^{134}$

There is some uncertainty associated with the process of obtaining clearance under the national security provisions. For investments which are subject to review or notification, there are filing requirements and timelines for determination of whether a review may be

Ibid, s 25.1(c).

Ibid, s 25.3(1).

Bill C-60, supra note 117, cl. 141(2).

ICA, supra note $1, \mathrm{~s} 25.3(1)$.

Ibid, s 25.2(1).

Ibid, s 25.3(3).

Ibid, s 25.2(3).

Ibid, s 25.2(4).

Ibid, s 25.4(1).

Ibid.

Ibid. 
ordered provided by regulations. ${ }^{135}$ However, for non-notifiable or non-reviewable investments there is no clearance process since the ICA does not require a filing to be made. In this case, the investor may choose to make the government aware of the investment to trigger the timeline as set out in the regulations.

Bill C-60 amended the national security timelines and extended a number of fairly short periods from five days to 30 days. In addition, the national security timelines may be extended on agreement of the Minister and foreign investor. ${ }^{136}$ While the amendments provide a foreign investor with the ability to negotiate extensions and thus appear to increase flexibility, a foreign investor would likely feel obliged to agree to such extensions in order to avoid a negative national security determination by the government. ${ }^{137}$

The adoption of a formal national security review regime seems to have been prompted by the proposed acquisition of MacDonald Dettwiler and Associates' Information Systems Business (MDA) by American defence contractor Alliant Techsystems (Alliant) in 2008. ${ }^{138}$ As there was no basis to reject the transaction on national security grounds, (then) Minister Jim Prentice blocked the acquisition on the grounds that it would not be of "net benefit" to Canada. ${ }^{139}$ Alliant would have gained access to MDA's proprietary Radarsat technology. ${ }^{140}$ Although MDA was firmly in support of the transaction and advocated its approval, the Minister rejected it on the grounds that it would be tantamount to handing governmentsubsidized technology “designed to protect Canada's sovereignty” over to the US. ${ }^{141}$ The Minister maintained this position "[e]ven though the firm would have continued to operate under a Canadian licence and the Canadian government would retain access to all data.”142 Accordingly, this transaction sent an early signal to the business community that the federal government is prepared to reject transactions on national security grounds.

The MDA case suggests that a transaction involving sensitive technology or sovereignty issues, even if the acquiror is from a strong ally of Canada, could be problematic. These issues have already arisen in the resources sector. In November 2008, Canadian-based uranium producer Forsys Metals Corp. (Forsys) announced that it was being acquired by George Forrest International Afrique S.P.R.L. (GFI), an African conglomerate involved in civil engineering, mining and manufacturing sectors. ${ }^{143}$ However, in August 2009, Forsys

National Security Review of Investments Regulations, SOR/2009-271.

Bill C-60, supra note 117, cl 141(2).

Michelle Lally et al, "Proposed Amendments to Investment Canada Act Capture Control-in-Fact Investments by State-Owned Enterprises," online: Osler <http://www.osler.com/NewsResources/ Government-Rejects-Petronas-Progress-Transaction-Is-Rejection-the-New-Reality-for-ForeignInvestors/>.

Industry Canada, "Minister of Industry Confirms Initial Decision on Proposed Sale of Macdonald, Dettwiler and Associates Ltd. to Alliant Techsystems Inc.," online: Canada News Centre < http://news. gc.ca/web/article-eng.do?crtr.sj1D=\&mthd=advSrch\&crtr.mnthndVl=\&nid=397499\& crtr.dpt1D=\&crtr.tp1D=\&crtr.lc1D=\&crtr.yrStrtVl=2008\&crtr.kw=\&crtr.dyStrtVl=26\&crtr.aud1D= \&crtr.mnthStrtVl=2\&crtr.yrndVl=\&crtr.dyndVl>.

Ibid.

"Federal government blocks sale of MDA space division," online: CBC News <http://www.cbc.ca/ news/business/story/2008/04/10/mdablock.html>.

Ibid.

J Anthony VanDuzer, “Mixed Signals: What Recent Developments Tell Us about Canadian Foreign Investment Policy” (2010) 10 Asper Review of International Business \& Trade Law 247 at 260.

Forsys, "George Forrest International Afrique S.P.R.L. to Acquire Forsys Metals Corp in Cash Transaction Valued at Approximately CAD \$579 Million,” online: Forsys Metals <http://forsysmetals. com/PDF/news/GFI\%20Takeover\%20NR-FINAL.pdf.>. 
announced that GFI had received a letter from Industry Canada prohibiting it from completing the proposed transaction pending further notice. ${ }^{144}$ Although no further details were released concerning the notice from Industry Canada, leaked diplomatic correspondence revealed concerns from both the Canadian and American governments that GFI planned to sell Forsys' uranium to Iran. ${ }^{145}$ We expect that transactions in the oil and gas sector will be more closely scrutinized on national security grounds as increasingly sophisticated heavy oil recovery technologies are developed and deployed in the oil sands and with continuing innovations in hydraulic fracturing techniques. ${ }^{146}$

National security issues may also arise in connection with international transactions in which Canadian assets form a part. The American government, which previously prohibited an attempt by CNOOC to acquire Unocal in 2005 on national security grounds, also scrutinized the CNOOC/Nexen transaction as a result of Nexen's offshore assets in the Gulf of Mexico. ${ }^{147}$ As US officials have been pressuring the Canadian government to adopt a more restrictive posture, ${ }^{148}$ investors may find themselves subject to more national security reviews in the oil and gas sector, especially if they are SOEs. ${ }^{149}$

\section{B. BREACHES OF UNDERTAKINGS}

Typically, the duration of undertakings provided to the Minister is three years. Undertakings relating to the acquisition of an oil and gas business can be challenging to craft because they normally have to assume a particular price level for three years into the future - notwithstanding the potentially significant market volatility that may exist for the commodity in respect of which such investment undertaking is required. As such, an undertaking relating to capital investment may be difficult to fulfill where the acquiror does not take a sufficiently long-term view in the face of such price volatility. It is also difficult for an investor to anticipate adverse changes which will render it uneconomic to follow through on investment plans especially if it is a new entrant into the Canadian market. Accordingly, there is a natural tension between the pressure on an investor to put forward significant undertakings in an effort to secure swift Ministerial approval, and the need for the investor to be cautious about commodity pricing assumptions to ensure it can fulfill the

Forsys Metals Corp, “GFI Investment Update,” online: Forsys Metals <http://forsysmetals.com/PDF/ News_2009/NRpercent20081909.pdf>.

145 Campbell Clark, "Nuclear worries behind failed Forsys deal: WikiLeaks" The Globe and Mail (17 January 2011), online: The Globe and Mail <http://www.theglobeandmail.com/report-on-business/ industry-news/energy-and-resources/nuclear-worries-behind-failed-forsys-deal-wikileaks/article $562745 />$.

146 Shawn McCarthy, "The oil patch enters a new technological era” The Globe and Mail (15 January 2013), online: The Globe and Mail <http://www.theglobeandmail.com/globe-investor/the-oil-patchenters-a-new-technological-era/article7375409> (stating that "A report prepared for federal-provincialterritorial energy ministers acknowledged that the energy sector has driven significant technological advancement. But it argued that government needs to work with industry to make Canada a global leader in energy innovation in order to leverage natural resources into sustainable wealth creation"). "CNOOC-Nexen deal wins key US regulatory approval," online: Reuters <http://www.reuters.com/ article/2013/02/12/nexen-cnooc-idUSL1N0BC1L120130212>.

148 Shawn McCarthy, “CNOOC's bid for Nexen fuels security concerns” The Globe and Mail (17 October 2012), online: The Globe and Mail <http://www.theglobeandmail.com/globe-investor/cnoocs-bid-fornexen-fuels-security-concerns/article4619564> (stating that "[a]t a panel discussion, Mr. Boisvert and Roger Robinson - a former official at the U.S. National Security Council - urged the Harper government to balance Ottawa's eagerness to expand trade and investment ties with China, with a 'eyes wide open' approach to security and threats from 'authoritarian capitalism'”).

149 The authors are aware of one recent transaction involving a SOE investigated on national security grounds. 
commitments. A cautious approach can appear uncooperative to the vendor and to the Investment Review Division of Industry Canada (the IRD), and may delay approval of the investment under the ICA.

However, in our experience, the IRD typically will not permit an investor to place conditions on the fulfillment of its undertakings based on commodity prices remaining at or above a certain level. Some comfort can be derived from administrative guidelines under the ICA which provide that "plans and undertakings are based to some extent on projected circumstances and the monitoring of an investor's performance will recognize this factor. Where inability to fulfill a commitment is clearly the result of factors beyond the control of the investor, the investor will not be held accountable."150

The ICA contains powerful enforcement mechanisms to compel an investor to perform its undertakings. These include the ability to issue a demand letter to require an investor to remedy the default, and the ability to apply for a court order directing an investor to comply with the undertaking. In addition, remedial measures such as a fine of $\$ 10,000$ per day of contravention, and orders of divestiture and revocation or suspension of voting rights may be sought. $^{151}$

Until recently, a breach of an investor's undertakings was handled discreetly by the IRD, and usually without threat of formal enforcement proceedings. However, formal enforcement is now a reality. In 2009, the Minister of Industry issued a demand letter which alleged that US Steel was not in compliance with its production and employment undertakings in connection with the acquisition of Stelco in $2007^{152}$ notwithstanding the worldwide slump in the steel industry after the 2008 financial crisis. For the first time in the history of the ICA, the Minister commenced court proceedings in early 2009. ${ }^{153}$ US Steel unsuccessfully challenged the constitutional validity of the ICA's penal provisions. ${ }^{154}$ US Steel then entered into a settlement with the Minister whereby it agreed to provide further undertakings. ${ }^{155}$

Industry Canada, All Guidelines, online: Industry Canada <http://www.ic.gc.ca/eic/site/ica-lic.nsf/ eng/lk00064.html\#p3>.

151 ICA, supra note 1, s 40. See the recent matter of Mobil Investments Canada Inc \& Murphy Oil Corporation v Canada (2012), ICSID Case No. ARB(AF)/07/4 (International Centre for Settlement of Investment Disputes), an arbitral tribunal at the International Centre for Settlement of Investment Disputes (ICSID) held that Guidelines for Research and Development Expenditures (online: C-N LOPB $<$ http://www.cnlopb.nl.ca/pdfs/ibguide/guidelines_for_research_and_develop ment_expenditures.pdf >) violated Chapter 11 of the North American Free Trade Agreement Between the Government of Canada, the Government of Mexico and the Government of the United States, 17 December 1992, Can TS 1994 No 2, 32 ILM 289 [NAFTA]. The ICSID tribunal held that the requirement under the CNLOPB Guidelines for investors to spend a fixed percentage of the revenues from offshore petroleum products within its jurisdiction contravened NAFTA Article 1106(1)(c), which prohibits a member state from requiring an investor "to purchase, use or accord a preference to goods produced or services provided in its territory, or to purchase goods or services from persons in its territory.” In contrast, NAFTA Annex 1138.2 exempts review decisions under the ICA from Chapter 11's dispute settlement provisions. ICA Annual Report, supra note 82 at 22 ("U.S. Steel had undertaken that, over three years, it would increase the annual level of production at the former Stelco facilities by at least 10 percent and that it would maintain an average aggregate employment level of not fewer than 3,105 employees on a fulltime equivalent basis"). Ibid.

154 Kevin Ackhurst, “Canadian government settles important Investment Canada Act case,” online: Lexology <http://www.lexology.com/library/detail.aspx?g=41acc611-75f1-46e9-8d23-d7ade6f9b39d> . Industry Canada, "Industry Minister Paradis Reaches an Out-of-Court Settlement in the U.S. Steel Litigation,” online: Industry Canada <http://www.ic.gc.ca/eic/site/064.nsf/eng/07011.html>. 
In our experience, the best practice to follow where the investor finds itself about to be in non-compliance with an undertaking is to advise the IRD as soon as possible and to negotiate a revised undertaking which it is able to meet. The ICA provides the Minister with the authority to accept a new undertaking from an investor. ${ }^{156}$

Alternatively, in a difficult case, the investor and the Minister may wish to consider using the relatively new Mediation Guideline, which was published under section 38 of the ICA after the resolution of the US Steel case. ${ }^{157}$ The investor and the Minister can agree to involve a third party mediator to facilitate resolution of a dispute about whether undertakings have been properly complied with and address key terms in the agreement including "the appointment of the mediator, confidentiality, the duration and termination of the mediation process, confidentiality, and cost sharing." 158

\section{BHP Billiton’s ATtempted ACQuisition OF PotASH CoRP.}

The statutory language pertaining to the determination of "net benefit" under the ICA is broadly worded. However, "[f]oreign investors ha[d] rarely given much thought to its provisions," given the history of allowing virtually all applications. ${ }^{159}$ The disapproval of BHP Billiton's ("BHP”) proposed acquisition of Potash Corp. has raised the question of how an investor can adequately address the ICA's enumerated factors for determining "net benefit," namely:

(a) the effect of the investment on the level and nature of economic activity in Canada, including, without limiting the generality of the foregoing, the effect on employment, on resource processing, on the utilization of parts, components and services produced in Canada and on exports from Canada;

(b) the degree and significance of participation by Canadians in the Canadian business or new Canadian business and in any industry or industries in Canada of which the Canadian business or new Canadian business forms or would form a part;

(c) the effect of the investment on productivity, industrial efficiency, technological development, product innovation and product variety in Canada;

(d) the effect of the investment on competition within any industry or industries in Canada;

(e) the compatibility of the investment with national industrial, economic and cultural policies, taking into consideration industrial, economic and cultural policy objectives enunciated by the government or legislature of any province likely to be significantly affected by the investment; and

(f) the contribution of the investment to Canada's ability to compete in world markets. ${ }^{160}$

ICA, supra note 1 , s 39.1 .

All Guidlines, supra note 150

Ibid.

Robert Todd, "Fortress Canada?” Canadian Lawyer Magazine (1 February 2011), online: Canadian Lawyer Magazine <http://www.canadianlawyermag.com/3596/Fortress-Canada.html>.

ICA, supra, note 1 , s 20. 
Industry Canada has published some limited guidance on how reviews of "net benefit" are conducted. ${ }^{161}$ The first step of the review process involves assessing the target business on "a stand-alone basis" as if the transaction had never occurred. ${ }^{162}$ The Minister of Industry will then take into account the overall financial health of the business as well as its relative strengths and weaknesses. ${ }^{163}$ The Minister then assesses the characteristics of the potential investor, and evaluates any benefits it may bring to the target business in the form of expertise, capital, strategic plans, or undertakings. ${ }^{164}$ The types of undertakings a potential investor can offer vary from case to case, but they typically include commitments relating to employment levels, capital spending, the participation of Canadians in various business functions, and commitments to invest in research and development. ${ }^{165}$ However, the relative weight assigned to each of the "net benefit" factors under section 20 of the ICA is deliberately made discretionary. As the ICA Annual Report states:

\footnotetext{
It is important to note that the [ICA] does not assign set weights to the factors nor does it indicate whether any factor is more important than another in the net benefit determination. Furthermore, not all factors may be relevant to a specific investment and some factors may be more relevant to one investment than to another. As each transaction presents its unique features, the Minister examines proposed investments on a case-bycase basis and makes his or her decision based on the facts and merits of each proposed investment. ${ }^{166}$
}

Accordingly, the wide Ministerial discretion, coupled with the breadth of the individual factors themselves, allows for politically-motivated decision-making and an inherent degree of uncertainty in the process. ${ }^{167}$

On 3 November 2010, the Minister of Industry, Tony Clement, announced that Australianbased BHP's \$39 billion hostile bid for Potash Corp. did not demonstrate a "net benefit” to Canada. Despite the hostile nature of the transaction, the decision came as a surprise to many observers, especially given the history of approvals under the ICA and the significant and unprecedented undertakings that BHP was prepared to offer, which included (among others):

- $\quad$ investing US\$450 million in exploration and development over a five year period and a further US\$370 million on infrastructure funds;

- $\quad$ maintaining employment levels at the Potash Corp.’s mines over a five year period, in addition to adding 200 jobs in Vancouver and Saskatchewan and increasing employment for the overall Potash Corp. business by 15 percent;

- $\quad$ foregoing various tax benefits to which it would be otherwise entitled; and

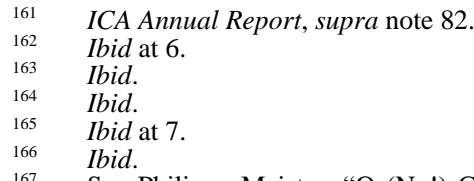

See Philippa Maister, “O (No!) Canada,” Corporate Counsel (January 2012) at 66, quoting Peter Glossop: "Ultimately, it is a political decision, and it doesn’t hurt to have good political relationships... The factors that are important depend on the region and what people in the industry consider important." 
- $\quad$ agreeing to be subject to an "unprecedented monitoring and compliance regime," which included a US\$250 million performance bond. ${ }^{168}$

The Potash Corp. bid evidenced that sensitivities associated with provincial politics can play a significant, if not determinative, role even if the ultimate decision-maker is the Minister. Saskatchewan Premier Brad Wall opposed the transaction on the basis that it "puts at risk a strategic natural resource," that its discontinued use of the Canpotex marketing company would “[put] \$6 billion worth of capital expansion and thousands of jobs at risk," and that it "would mean a significant loss in provincial revenues." 169 The Premier was also concerned about the ability of the federal government to enforce undertakings, notwithstanding the proceedings taken against US Steel. Minister Clement also cited the fact that BHP lacked expertise in potash mining and marketing. ${ }^{170}$

However, independent analysis showed that, on the whole, the transaction would have been beneficial to Saskatchewan. The province of Saskatchewan commissioned the Conference Board of Canada (the CB), which is an independent non-profit organization, to assess the impact of the transaction on the province. ${ }^{171}$ As part of its methodology, the CB collected various quantitative data relating to global supply and demand patterns, as well as conducted numerous interviews with affected parties and industry experts. ${ }^{172}$ Although BHP was criticized for its lack of experience in the potash industry, the CB noted that the acquisition of Potash Corp. was a logical addition to BHP's diversified resources portfolio. ${ }^{173}$ The CB ultimately concluded that "[o]ur analysis indicates that an acquisition by [BHP] would appear to be of minimal risk to the Province, even if [BHP] did not wish to continue [Potash Corp's] relationship with Canpotex in the long term." ${ }^{174}$ The CB specifically mentioned that there was no real risk that Potash Corp. would be "hollowed out." 175 Despite all of these findings, however, Premier Wall and Minister Clement maintained their opposition to the transaction.

Although section 20(e) of the ICA provides that the "net benefit" assessment includes the "consideration [of] industrial, economic and cultural policy objectives enunciated by the government or legislature of any province likely to be significantly affected by the investment," ${ }^{176}$ provincial pressure likely had an especially profound impact for several reasons. Commentators have noted that Stephen Harper's minority government relied on seats from 13 out of 14 electoral districts in Saskatchewan, and was especially vulnerable to

BHP, "BHP Billiton Withdraws Its Offer To Acquire PotashCorp And Reactivates Its Buy-back Program” (15 November 2011), online: BHP Billiton <http://www.bhpbilliton.com/home/investors/ news/Pages/Articles/BHP\%20Billiton\%20Withdraws\%20Its\%20Offer\%20To\%20Acquire\%20Potash Corp\%20And\%20Reactivates\%20Its\%20Buy-back\%20Program.aspx>.

Government of Saskatchewan, "Premier Wall Says Province Cannot Support Potash Takeover Bid,” online: Government of Saskatchewan <http://www.gov.sk.ca/news?newsId=9c2ac5ac-ccf6-4923-96dcd6efaa38007e > [Wall Statement]. See also Todd, supra note 159.

Sonali Paul, "BHP kills Potash Corp bid, revives $\$ 4.2$ billion buyback," online: Reuters <http://www. reuters.com/article/2010/11/15/us-potashcorp-bhpbilliton-idUSTRE6AD2FA20101115>.

The Conference Board of Canada, Saskatchewan in the Spotlight: Acquisition of Potash Corporation of Saskatchewan Inc. - Risks and Opportunities, online: Government of Saskatchewan <http://www. gov.sk.ca/adx/aspx/adxGetMedia.aspx?mediaId=1245\&PN=Shared $>$.

Ibid at 4.

Ibid at 38

Ibid at 61 .

Ibid at 55 .

ICA, supra note 1 , s $20(\mathrm{e})$. 
losing provincial support in the upcoming 2011 election. ${ }^{177}$ This concern was likely magnified by the fact that other provinces had sided with Saskatchewan and opposed the bid. ${ }^{178}$ Second, Premier Wall had suggested that the province may initiate litigation if the bid was allowed to proceed, and the federal government may have wished to avoid a constitutional challenge over the provincial control of natural resources. ${ }^{179}$

The absence of official federal government reasons for the Potash Corp. decision has prompted further questions on potential implications for the energy sector. As BHP decided to discontinue its bid instead of making additional submissions to demonstrate a "net benefit," the Minister apparently took the technical view that since he did not need to issue a final rejection of the transaction, written reasons were not required for the initial decision. ${ }^{180}$ It remains to be seen whether other cases in the natural resource sector, potentially including oil and gas, will be disapproved on the basis that they involve a "strategic resource." ${ }^{181}$ As discussed below, the most recent federal policy announcement in effect puts the oil sands into the category of a "strategic resource," the control of which is now unavailable to SOEs.

The BHP case reminded investors that the review and approval process under the ICA is inherently political. In this sense it differs fundamentally from other regulatory approvals which are principles-based and made by an independent board, commission, or tribunal. As a result, an investor must anticipate politically sensitive issues well in advance of applying for approval. Ideally, the investor will have carefully prepared the way for approval by "taking the temperature" of political, industry, and media stakeholders, building relationships and opening up lines of communication, and addressing their concerns by way of carefullycrafted media statements about the transaction and appropriate undertakings. ${ }^{182}$ However, outside of the SOE context, certain transactions will continue to carry some approval risk, particularly hostile bids for iconic Canadian companies with significant industry positions or representing a "strategic resource."

Todd, supra note 159.

Ibid.

James Wood, "Premier Brad Wall not ruling out legal fight with feds over potash” (2 November 2010), online: Regina Leader-Post <http://www.leaderpost.com/news/Premier+Brad+Wall+ruling+legal+fight+ with+feds+over+potash/3761076/story.html>.

Todd, supra note 159.

Eric Reguly, Andy Hoffman \& Brenda Bouw, "BHP’s hopes fade as Ottawa calls potash 'strategic,'” The Globe and Mail (4 November, 2010), online: The Globe and Mail <http://www.theglobeandmail. com/globe-investor/bhps-hopes-fade-as-ottawa-calls-potash-strategic/article1216182/>. See also Wall Statement, supra note 169 ("strategic natural resource").

182 In this regard, CNOOC set out an impressive list of proposed undertakings when it announced the proposed acquisition of Nexen Inc., see Nexen, "CNOOC Limited Enters Into Definitive Agreement to Acquire Nexen Inc,” online: Nexen <http://www.nexeninc.com/en/AboutUs/MediaCentre/News Releases/News/Release.aspx?year=2012\&release_id=130738> [Nexen Press Release]. 


\section{The State-OWNed ENTERPRISEs Problem}

The "SOE problem” has been neatly summarized as follows:

By turning companies into organs of the government, state capitalism simultaneously concentrates power and corrupts it. It introduces commercial criteria into political decisions and political decisions into commercial ones. ${ }^{183}$

Advantage Canada had articulated a concern over SOE investments in 2006. New guidelines for SOEs were introduced in 2007, even before the Competition Policy Review Panel had completed its work. The key policy concern of the government as stated in the SOE Guidelines was to "ensure that the governance and commercial orientation of SOEs are considered in determining whether reviewable acquisitions of control in Canada by the SOE are of net benefit to Canada.” 184

The policy considerations in the SOE Guidelines are worth quoting extensively:

When assessing whether such acquisitions of control are of net benefit to Canada, the Minister will examine, as part of the assessment of the factors enumerated in section 20 of the Act, the corporate governance and reporting structure of the non-Canadian. This examination will include whether the non-Canadian adheres to Canadian standards of corporate governance (including, for example, commitments to transparency and disclosure, independent members of the board of directors, independent audit committees and equitable treatment of shareholders), and to Canadian laws and practices, including adherence to free market principles. The Minister will assess the effect of the investment on the level and nature of economic activity in Canada, including the effect on employment, production and capital levels in Canada. The examination will also cover how and the extent to which the non-Canadian is owned, controlled by a state or its conduct and operations are influenced by a state.

Furthermore, the Minister will assess whether a Canadian business to be acquired by a non-Canadian that is an SOE will likely operate on a commercial basis, including with regard to:

- where to export;

- where to process;

- the participation of Canadians in its operations in Canada and elsewhere;

- the impact of the investment on productivity and industrial efficiency in Canada;

- $\quad$ support of on-going innovation, research and development in Canada; and

- the appropriate level of capital expenditures to maintain the Canadian business in a globally competitive position. 
Specific undertakings related to these issues may assist to supplement a non-Canadian's plans for the Canadian business. Examples of undertakings that have been used in the past and could be used in the future, include, among other undertakings, the appointment of Canadians as independent directors on the board of directors, the employment of Canadians in senior management positions, the incorporation of the business in Canada, and the listing of shares of the acquiring company or the Canadian business being acquired on a Canadian stock exchange. Appropriate monitoring will be conducted in accordance with the ICA. ${ }^{185}$

In effect, under the SOE Guidelines, SOEs were permitted to acquire Canadian businesses so long as they operated in a sufficiently transparent and commercial manner, in effect mimicking private-sector enterprises and suppressing their innate non-transparency and noncommercial objectives. Although the SOE Guidelines indicated a shift toward a higher level of scrutiny for SOE investments, numerous high profile investments by SOEs in the oil and gas industry continued to receive approval after the new SOE Guidelines were issued. In fact, the timing of this policy turned out to accurately predict an unprecedented wave of material SOE investment in Canada, which included:

- $\quad$ PetroChina International Investment Company’s CDN\$1.9 billion acquisition of a 60 percent interest in two oil sands projects from Athabasca Oil Sands Corp. (2009);

- $\quad$ Korea National Oil Corporation’s CDN\$4.1 billion acquisition of Harvest Energy Trust (2009);

- International Petroleum Investment Company’s US\$2.3 billion acquisition of NOVA Chemicals Corp. (2009);

- China Investment Corp’s CDN\$2.6 billion joint venture with Penn West Energy Trust (2010);

- $\quad$ PTT Exploration and Production’s US\$2.28 billion acquisition of a 40 percent interest in oil sands assets from Statoil (2010);

- $\quad$ Sinopec’s US\$4.65 billion acquisition of ConocoPhillips’ stake in Syncrude (2010);

- $\quad$ CNOOC’s US\$2.1 billion acquisition of OPTI Canada Inc. (2011);

- $\quad$ Sinopec’s CDN\$2.2 billion acquisition of Daylight Energy (2011);

- Harvest Operations Corp.'s CDN\$525 million acquisition of producing and undeveloped assets from Hunt Oil Company of Canada (2011);

- $\quad$ PetroChina's acquisition of control of the entity which held a 20 percent interest in Shell Canada Energy’s Groundbirch project (2011); ${ }^{186}$ and

Michelle Lally et al, "New Rules for Foreign Investment by State-Owned Enterprises — Do They Strike the Right Balance?” (9 December 2012), online: Osler <http://www.osler.com/NewsResources/NewRules-for-Foreign-Investment-by-State-Owned-Enterprises-Do-They-Strike-the-Right-Balance/>. 
- INPEX Corporation-led Japanese consortium’s CDN\$700 million acquisition of a 40 percent joint venture interest in Northeast British Columbia shale gas assets from Nexen Inc. (2011).

However, the pace of SOE investment accelerated rapidly in scale in 2012. Two significant acquisitions by non-Canadians had been announced earlier in the year, namely Progress Energy Resources Corp.’s (Progress) CDN\$6 billion acquisition by Malaysian government-controlled Petronas and Nexen Inc.'s (Nexen) \$15.1 billion acquisition by China National Offshore Oil Corporation (CNOOC), a Chinese state-owned corporation. ${ }^{187}$

On 19 October 2012, Minister Christian Paradis announced the Progress/Petronas transaction had not demonstrated a "net benefit" to Canada, subject to Petronas demonstrating the contrary through additional submissions within 30 days. This represented the first time that Industry Canada had refused to approve an investment in the oil and gas sector, and by a SOE. Apparently, the preliminary decision was rendered because Petronas had refused to agree to a further extension of the review period, not because the package of undertakings was unacceptable. ${ }^{188}$

The CNOOC transaction was particularly controversial given its size (at CDN\$15.1 billion, the largest foreign acquisition by a Chinese SOE ever) ${ }^{189}$ The combined value of both the CNOOC and Petronas deals at over CDN\$20 billion exceeded some estimates of total Asian investment to that time in the Canadian non-conventional oil and gas sector. ${ }^{190}$

Industry Canada eventually approved both the Petronas/Progress and CNOOC/Nexen transactions on 7 December 2012. It also released updated SOE guidelines and its own statements in conjunction with statements from Prime Minister Harper on the same day (collectively, the "December 7 Announcements"). ${ }^{191}$ The announcements from both the Prime Minister and Industry Canada specified several changes to government policy on foreign investment in the energy sector going forward.

No reasons were given for the approvals of the Petronas/Progress and CNOOC/Nexen transactions. In retrospect, any reasons likely would have been misleading indicators of the government's ICA policy going forward. In fact, Minister of Natural Resources Joe Oliver

Ibid.

Peter Glossop \& Frank Turner, “Government Rejects Petronas-Progress Transaction: Is Rejection the New Reality for Foreign Investors?,” online: Osler <http://www.osler.com/NewsResources/Govern ment-Rejects-Petronas-Progress-Transaction-Is-Rejection-the-New-Reality-for-Foreign-Investors/>. "Nexen buyout-China's largest foreign acquisition," online: The BRICS Post < http://thebricspost.com/ nexen-buyout-chinas-largest-foreign-acquisition/>.

Frank Turner, Peter Glossop \& Chris Murray, “Asian Investment in Canada’s Resource Sector in 2012,” online: Osler < http://www.osler.com/uploadedFiles/News-and-Resources/Publications/Guides/CapitalMarkets-Review-2012/2012\%20Markets\%20Review\%20-\%20ch\%202.pdf>.

"Statement by the Prime Minister of Canada on foreign investment," online: Prime Minister of Canada <http://www.pm.gc.ca/eng/media.asp?category=3\&id=5195> [Harper Statement]; Industry Canada, “State-Owned Enterprises,” online: Industry Canada <http://www.ic.gc.ca/eic/site/064.nsf/eng/07248. html>; All Guidelines, supra note 150; Industry Canada, "Review Threshold” (7 December 2012), online: Industry Canada <http://www.ic.gc.ca/eic/site/064.nsf/eng/07249.html>. 
commented shortly afterwards that the CNOOC/Nexen proposal would not have been approved under the new policy prohibiting acquisitions of control of oil sands businesses. ${ }^{192}$

\section{INVESTMENTS BY SOES IN THE OIL SANDS ONLY IN "EXCEPTIONAL CIRCUMSTANCES"}

Although the Petronas/Progress and CNOOC/Nexen transactions received government approval on 7 December 2012, at the same time Prime Minister Harper signalled an end to the trend of foreign government ownership in the Canadian oil sands. Harper specifically stated that

[i]n light of growing trends, and following the decisions made today, the Government of Canada has determined that foreign state control of oil sands development has reached the point at which further such foreign state control would not be of net benefit to Canada... going forward, the Minister will find the acquisition of control of a Canadian oil-sands business by a foreign state-owned enterprise to be of net benefit, only in an exceptional circumstance. ${ }^{193}$

In effect, the oil sands sector was declared to have reached a level of SOE ownership beyond which the government would be concerned about undue foreign government influence. The ban on future SOE investments in effect was an acknowledgement by the government that the SOE Guidelines perhaps would not be effective in tempering the undesirable effects of SOE investments, and that a case-by-case approach was inadequate. This is interesting in light of the IRD's practice in specific cases of requesting undertakings from SOEs of indefinite duration concerning the governance and commercial orientation components of the SOE Guidelines.

The December 2012 ban on SOE investment is perhaps not surprising given the global importance of oil sands, which contribute to Canada ranking third to Saudi Arabia and Venezuela in crude oil reserves and perhaps, more importantly, provide 55 percent of the world's oil reserves that are open to the private sector. ${ }^{194}$ And even though Nexen may have what appears to be a relatively less significant position in the oil sands given its current levels of production, its reserves tell a different story. ${ }^{195} \mathrm{CNOOC}$ was able to add 900 million barrels of oil equivalent reserve through the acquisition and increase CNOOC's proven reserves by 30 percent. ${ }^{196}$ Significantly, CNOOC also acquired 1.3 billion barrels of oil equivalent resources primarily from Nexen's oil sands interests at Long Lake and Syncrude

192 “Canadian P.M. vows to block further Chinese ownership in oil sands” (10 December 2012), online: CBS News.com <http://www.cbsnews.com/8301-505123_162-57558318/canadian-p.m-vows-to-blockfurther-chinese-ownership-in-oil-sands/>.

193 Harper Statement, supra note 191.

194 Dave Collyer, Canadian Oil and Gas Industry Outlook - Opportunities and Challenges (3 October 2012), online: Canadian Association of Petroleum Producers <http://www.capp.ca/getdoc.aspx?dt=ntv \&docID $=213962>$.

195 The top five oil sands bitumen players are Suncor (Canadian), Imperial Oil Ltd., Canadian Natural Resources Ltd. (Canadian), Royal Dutch Shell, and Canadian Oil Sands Ltd. (Canadian). Nexen is eighth. See Jacquie McNish \& Carrie Tait, “China’s road to Calgary” The Globe and Mail (15 December 2012), online: <http://advisor1.dynamic.ca/servlet/ArticleNews/story/gam/20121215/RBCHINA OILPATCHPRINTFINAL1214ATL>.

196 Claudia Cattaneo, “China’s CNOOC to buy Nexen for \$15.1-billion,” National Post (23 December 2012), online: National Post <http://www.business.financialpost.com/2012/07/23chinas-cnooc-to-buynexen-for-15-1-billion/>. 
and from its shale gas portfolio. ${ }^{197}$ This has significant implications for control transactions in other oil and gas sectors which were not affected by the December 7 Announcements, such as natural gas.

Prime Minister Harper's decision not to elaborate on the meaning of "exceptional circumstance” in the new policy leaves open the possibility some oil sands takeovers by SOEs could be allowed. Whether an oil sands business in financial difficulty could be acquired (in a reprise of the approach taken under the Masse Policy) is uncertain. The notion of "exceptional circumstance" also leaves open the possibility that contractual rights that were created prior to the December 7 Announcements may be recognized.

Some transactions which involve control having been obtained prior to 7 December 2012 seem to be outside the scope of the new policy. For example, in 2009, PetroChina International Investment Company Limited (PetroChina) acquired a 60 percent ownership interest in the Mackay River and Dover oil sands projects from Athabasca Oil Sands Corp. (Athabasca) with an additional 40 percent divestiture option to be exercisable following certain regulatory approvals. ${ }^{198}$ In 2012, PetroChina elected to purchase the additional 40 percent interest in the Mackay River project while the Dover project is still awaiting regulatory approval. According to Athabasca's chief executive officer, Sveinung Svarte, the entire transaction, including the additional divestiture option, was reviewed and approved by Investment Canada in 2009, when the initial transaction was announced. ${ }^{199}$ Since PetroChina already holds a 60 percent interest, if it elects to acquire the additional 40 percent interest in the Dover project from Athabasca it would normally not be subject to additional ICA review, even under the new SOE Guidelines, because PetroChina already holds a greater than 50 percent interest and is already deemed to control the Dover project.

It is also possible that a SOE may have treated an option to acquire a controlling interest in a Canadian oil sands business as having been exercised as permitted under section 30(1) of the ICA, and submitted a notification or application for review prior to the December 7 Announcements. When it actually exercises the option, and acquires control, the transaction should be exempt from the new policy. Outside of this situation, however, there may be other pre-existing private arrangements that were not previously subject to ICA review and it is unclear whether such arrangements may be accorded special "grandfathered" status on the basis that parties have relied on the prior policy which permitted an acquisition of control. For example, a SOE with a minority investment in an oil sands business may have rights of first refusal that would enable it to acquire a controlling interest in the event of a proposed share sale by another shareholder. Or is the political nature of the process such that the policy change in December 2012 must determine the outcome? And should a SOE that is prepared to offer exceptional "net benefits" (for example, significant increases to employment and

See Nexen, Nexen Inc., Annual Information Form, online: Nexen <http://www.nexeninc.com/en/ investors/ /media/Files/Annual/Reports/2012/Nexen-2012-AIF.ashx>.

Government of Canada, "Industry Minister Clement Approves the Petrochina-Athabasca Oil Sands Corporation Transaction,” online: Canada News Centre <http://news.gc.ca/web/article-eng.do?m=/ index\&nid=504339>.

Carrie Tait, “Athabasca deal gives China an oil sands project of its own,” The Globe and Mail (3 January 2012), online: The Globe and Mail <http://m.theglobeandmail.com/report-on-business/industry-news/ energy-and-resources/athabasca-deal-gives-china-an-oil-sands-project-of-its-own/article4085184/>. 
capital expenditures, etc.) be allowed to acquire control? Unfortunately, answers to these questions will only be determined through actual experience.

Other questions regarding the new policy include the definitions of "oil sands" and "oil sands business.” To what extent does a target business have to be engaged in upstream extraction of bitumen from oil sands to be caught by the policy? Are downstream industry participants involved in upgrading and distribution affected by the new policy? Presumably pure exploration properties with no reserves and production will continue to be considered outside the scope of the ICA and hence the policy. ${ }^{200}$

Further, what is meant by "the acquisition of control of a Canadian oil-sands business by a foreign state-owned enterprise"? Should this be read (1) expansively where there is more than one SOE investor over a period of time, and collectively their interests would exceed 50 percent of the shares of a corporation or 50 percent of the interests of a joint venture, or (2) narrowly, so that the normal acquisition of control rules apply, assuming, of course, that the SOEs have not formed a voting group or joint venture? Given pending amendments to the ICA concerning acquisition of control in fact by SOEs, as discussed below, in policy terms it may be risky to rely upon technical control arguments to avoid potential application of the new policy.

While the December 7 Announcements appeared to provide the reassuring certainty that non-controlling SOE minority investments will "continue to be welcome,"201 Bill C-60 introduced amendments which provide the Minister with new powers to determine whether an entity is "controlled in fact" by a SOE and its investment therefore subject to the SOE Guidelines. ${ }^{202}$ Notably, this discretion applies even to entities that otherwise qualify as Canadian-controlled entities under the ICA. ${ }^{203}$ The introduction of the "control in fact" concept has introduced further uncertainty to the treatment of SOE investments and, in particular, to transactions that have been structured as minority investments that do not amount to control in under the normal "control in law" rules in the ICA.

What is meant by an acquisition of control in fact by a SOE? While Bill C-60 did not define control in fact, a number of other federal agencies have defined control in fact as the ability of a person to "determine or decide the strategic decision-making activities of an enterprise and the ability to manage and run its day-to-day operations." ${ }^{204}$ While minority investors may have a degree of influence over an entity, in order for there to be control in fact such influence must be “dominant or determining." 205

“Interpretation Note 4," supra note 79.

"State-Owned Enterprises," supra note 191. Indeed, this occurred very close to the announcement of PetroChina's and Encana’s shale gas joint venture, see Encana, "Encana Announces Joint Venture to Develop Duvernay Lands,” online: Encana <http://www.encana.com/news-stories/news-releases/ details.html?release $=726812>$ [Encana Press Release $]$.

Ibid.

Canadian Transport Agency, “Interpretation Note: Control in Fact,” online: Canadian Transport Agency $<$ http://www.cta-otc.gc.ca/eng/control-in-fact> ["Control in Fact”]. See also Industry Canada, Spectrum Management and Telecommunications, "CPC-2-0-15 - Canadian Ownership and Control," online: Industry Canada <http:// www.ic.gc.ca/eic/site/smt-gst.nsf/eng/sf01773.html>. Ibid. 
The new SOE rules on control in fact apply to all foreign SOEs without regard to their nationality. Although there has been some suggestion that the new Canada-China investment treaty will enable Chinese investors in the oil sands to be treated in the same way as Canadian investors, ${ }^{206}$ it is clear that the Canada-China FIPA does not exempt Chinese investors from the application of the ICA in the same way Canadian investors are exempt from the ICA. Article 8(2)(a) of the Canada-China FIPA provides that existing protectionist measures such as the ICA are not affected by the commitments in the Canada-China FIPA concerning most-favoured-nation treatment, national treatment and senior management, boards of directors, and entry of personnel. ${ }^{207}$

It is also important to consider the implications of Prime Minister Harper's use of the phrase "oil sands business" in light of the non-conventional business involving liquefied natural gas (LNG) based on shale gas. As SOEs are involved in three out of the five announced LNG projects on the West Coast questions have arisen as to why these types of investments were not similarly covered by the new policy. ${ }^{208}$ Several factors distinguish the oil sands from the developing LNG export industry, including: (1) the relative maturity of the oil sands industry, compared to the more nascent LNG industry that requires extensive capital investment not available from non-SOE sources; (2) the LNG industry is overwhelmingly supported by the British Columbia government which understands the economic benefits associated with such development and that such benefits are contingent upon SOE participation; and (3) the competitive tension created by substantial international competition to serve Asian markets that could thwart the economic viability of some of the Canadian projects. ${ }^{209}$ In addition, the federal government likely appreciated that such projects have a much better chance of reaching commercial viability if they are sponsored by the most likely customers for Canadian LNG exports, which happen to be SOEs in countries such as China, Korea, Japan, and Malaysia where natural gas prices are significantly higher than in North America. The oil sands differ in this respect, as most of the bitumen and upgraded oil currently remains in North America.

However, one should not assume that SOE investments in the non-conventional energy industries, as well as other industries more generally, will escape a high level of scrutiny. Prime Minister Harper specifically stated that “[o]utside the oilsands, our Government will strengthen scrutiny under the Act of proposals by foreign state-owned enterprises to acquire Canadian businesses." 210 The Prime Minister made it clear in this context that "some of the considerations that would be factored into a review" of such acquisitions include:

Agreement Between the Government of Canada and the Government of the People's Republic of China for the Promotion and Reciprocal Protection of Investments, 9 September 2012 [Canada-China FIPA Treaty]; Deborah Yedlin, "Mulcair hits wrong note on foreign investment - NDP Leader Ventures Into Oil Country," Calgary Herald (20 February 2013), online: Osler <http://www.osler.com/News Resources/Details.aspx?id=5496>. Recounting NDP leader Thomas Mulcair's comments at a recent chamber of commerce luncheon that "[u]nder article 6 of the FIPA, once a Chinese company is established in Canada, it must receive national treatment for expansion in operations, meaning Canada must treat it as if it were any other Canadian company." Canada-China FIPA Treaty, ibid. See also Annex D.34, which exempts decisions under the ICA from being challenged under the Canada-China FIPA's general dispute resolution mechanism under Article 15. ARC Financial Corp <http://arcfinancial.com/research/energy-charts/bc-lng---its-a-crowded-coast/>; Lally et al, supra note 186 . Ibid.

$210 \quad$ Harper Statement, supra note 191. 
First, the degree of control or influence a state-owned enterprise would likely exert on the Canadian business that is being acquired.... Second, the degree of control or influence that a state-owned enterprise would likely exert on the industry in which the Canadian business operates.... Third, and most importantly, the extent to which the foreign government in question is likely to exercise control or influence over the state-owned enterprise acquiring the Canadian business. ${ }^{211}$

The government indicated that it will take (unspecified) action where "due to a high concentration of ownership a small number of acquisitions of control by SOEs could undermine the private sector orientation of an industry."212 Accordingly, SOEs considering control transactions in other oil and gas businesses should consider acting quickly to obtain the first-mover advantage before a particular sector is subjected to investment restraints similar to the oil sands. Although there may not be outright prohibitions on acquisitions of control outside of the oil sands, SOE acquisitions of control (or those that are found to be acquisitions of control in fact) may be subject to lengthier reviews or requests for more onerous undertakings.

Certain participants in the oil sands have already expressed concerns about finding potential buyers for assets they wish to sell. For example, ConocoPhillips, which had announced that it intended to divest itself of certain interests in the oil sands, recently stated that "[c]ertain kinds of buyers and certain kinds of deal structures may have a more difficult time in Canada as a result of the investment Canada decisions that came through the Progress deal with Petronas and through the CNOOC deal with Nexen."213

\section{ANNOUNCEMENT ON SOE REVIEW THRESHOLDS AND CHANGES TO THE SOE GUIDELINES}

As part of the December 7 Announcements and as implemented by Bill C-60, ${ }^{214}$ Industry Canada announced that planned changes to the review thresholds under the ICA will not apply to SOEs, which will continue to remain subject to the CDN\$344 million asset value threshold. As discussed below, whether such changes will actually result in a relatively higher number of reviews for SOEs as opposed to non-SOEs remains to be seen.

Various changes to the SOE Guidelines were also announced. Among the changes was new language in the definition of SOE referencing entities "influenced directly or indirectly" by a foreign government in addition to direct or indirect ownership and control. ${ }^{215}$ Bill C-60 further expanded the definition of SOE to include not only entities "influenced” by, but also individuals "acting under the direction," directly or indirectly, of a foreign government or agency. ${ }^{216}$ The nebulous concepts of "influence” and "direction" without further clarification represent a potentially profound expansion of the definition of SOE. Aside from businesses

Ibid.

Industry Canada, "Statement Regarding Investment by Foreign State-Owned Enterprises," online: Industry Canada <http://www.ic.gc.ca/eic/site/ica-lic.nsf/eng/lk81147.html>.

Anna Driver, "Canada's foreign investment rules making it difficult to do deals: ConocoPhillips," The National Post (28 February 2013), online: Financial Post <http://business.financialpost.com/2013/ 02/28/canadas-foreign-investment-rules-making-it-difficult-to-do-deals-conocophillips/>.

"Review Threshold," supra note 191; Bill C-60, supra note 117, cl. 137(1.1).

All Guidelines, supra note 150.

Bill C-60, supra note 122, cl 136(2). 
that have government shareholders, businesses that benefit from significant government loans, subsidies, or grants might now be considered SOEs if they can be considered to be "influenced" by such arrangements. It is also conceivable that the past governmental roles of senior management, or ongoing personal relationships between executives and government officials may suffice. $^{217}$

The SOE Guidelines have been amended to reference the additional criteria of the SOE's "adherence to free market principles" and "the effect of the investment on the level and nature of economic activity in Canada, including the effect on employment, production and capital levels in Canada" as factors for determining a "net benefit." 218 The "impact of the investment on productivity and industrial efficiency in Canada" was also added as a consideration for whether a SOE operates on a commercial basis. ${ }^{219}$ As the updates to the SOE Guidelines specifically place the burden of proof on the SOE to demonstrate its satisfaction of the criteria, ${ }^{220}$ it will be necessary to engage in a considerable level of diligence on a SOE's business model to assure the IRD and the Minister that a SOE satisfies the criteria in the SOE Guidelines.

\section{E. Changes TO GeNERAL REVIEW THRESHOLDS}

The December 7 Announcements reiterated the government's intention, to eventually increase the review threshold for non-SOEs to CDN\$1 billion based on enterprise value so that only the most significant transactions would be subject to review. ${ }^{221}$ Draft regulations published on 2 June 2012 proposed that enterprise value would be based upon market capitalization (plus liabilities minus cash and cash equivalents) for publicly traded companies and the total acquisition value (plus liabilities minus cash and cash equivalents) for asset acquisitions and acquisitions of private business. ${ }^{222}$

Although this development was intended to represent a liberalization of the application of the ICA, ${ }^{223}$ observers have questioned whether the opposite effect will occur and whether more transactions will be captured "because, in most cases, enterprise value is likely to

See United States, House of Representaives Permanent Select Committee on Intelligence, Investigative Report on the U.S. National Security Issues Posed by Chinese Telecommunications Companies Huawei and ZTE, online: Permanent Select Committee on Intelligence <http://www.intelligence.house.gov/ sites/itelligence.house.gov/files/Huawei-Zte\%20Report\%20(final).pdf $>$. This report was issued in connection with an investigation into the US business activities of Huawei Technologies Company and ZTE, two Chinese telecommunications companies. Notably, the report cites the lack of clarity around the relationships between various individuals at both companies and the Chinese government and states at 41: "[t]o the extent these executives and Board Members have obligations to both the company's shareholders and the State through the Communist Party, there is an inherent conflict of interest in their duties, and this statement provides confirmation that the Party likely does in fact have influence and input into the business affairs of the company through these individuals.” All Guidelines, supra note 150.

Ibid.

Ibid.

ICA, supra note 1, s 14.1 (amendment not in force). See "Review Threshold, supra note 191.

"Proposed Changes to the Investment Canada Act and Foreign Investment Review Process Benefit or Increased Burden for Foreign Investors?,” online: Osler <http:/www.osler.com/NewsResources/ Proposed-Changes-to-the-Investment-Canada-Act-and-Foreign-Investment-Review-Process-Benefit-orIncreased-Burden-for-Foreign-Investors/> ["Proposed Changes"]; Regulations Amending the Investment Canada Regulations, (2012) C Gaz 1, 1464-65 (inserting section 3.2); ibid at 1465-66 (inserting section 3.3).

223 "Review Threshold," supra note 191. Stating that "In ... [implementing the new thresholds], the Government is liberalizing the review process for private sector businesses." 
substantially exceed book value.”224 This concern is especially acute for the transitional years of the increase, when the enterprise value threshold will only be CDN\$600 million for the first two years and CDN\$800 million for the subsequent two years. ${ }^{225}$ Depending on the market capitalization and balance sheet composition of a particular oil and gas business, it is entirely possible that transactions that would not have been reviewable previously because they did not meet the book value threshold may now be reviewable because the transaction exceeds the applicable enterprise value threshold.

This development is also likely to add complexity to the reviewability of certain transactions. Oil and gas assets typically have a determinable book value; however, an enterprise value can be subject to interpretation. For instance, conventional oil and gas transactions can include consideration in the form of land swaps or undeveloped or previously developed and abandoned land where the total acquisition value and liabilities may not be apparent.

\section{COMMERCIAL IMPLICATIONS}

Admittedly, recent developments raise more questions than they answer in terms of the type of outcomes non-Canadians investing in the oil and gas industry can expect in the foreign investment review process. Most cases should continue to be reviewed and approved in a straightforward manner. Although most would agree that the regime has not reverted back to the restrictive era of the FIR Act and the NEP, there are clear signs that certain foreign investments will become more difficult and time consuming. ${ }^{226}$

\section{A. BENEFITS OF FOREIGN INVESTMENT IN THE CANADIAN OIL AND GAS INDUSTRY}

The SOE Guidelines and December 7 Announcements have forced investors to take a step back and to re-evaluate the deal landscape. While the ICA changes have seemingly dampened foreign investment opportunities in Canada, we believe that structuring considerations will become that much more important, particularly for SOEs. In addition, the fact remains that the Canadian resource sector will undoubtedly continue to benefit from access to foreign markets and capital and in fact needs foreign capital to advance capital intensive oil sands developments and shale gas resource plays. Along with the evident need to diversify the markets that Canada supplies its oil and gas to, primarily motivated by reductions in US demand for Canadian resources and the growth in Canadian reserve potential, access to

VanDuzer, supra note 142 at 255.

226 "Proposed Changes," supra note 222.

The tone of statements made by the other federal political parties suggests that they are inclined to take an even more restrictive stance on foreign investment than the current Conservative government. See e.g. "Goodale Commentary — What Do Canadians Want From Foreign Investment?,” online: Liberal Party of Saskatchewan <http://saskatchewan.liberal.ca/news/goodale-commentary-what-do-canadianswant-from-foreign-investment/> (the Liberal Party recalling how "a number of former Canadian 'champions' in the natural resources sector have been bought-out by foreign owners” and warning of (at the time) "looming" takeovers from CNOOC and others and the need for reciprocity); "Harper government irresponsible in approving Nexen takeover,” online: New Democratic Party <http:// www.ndp.ca/news/harper-government-irresponsible-approving-nexen-takeover> (stating that "New Democrats are profoundly disappointed that the Conservative government has decided to rubber stamp the Nexen takeover deal by CNOOC ... [t] he sale of Nexen to Chinese state-owned CNOOC raises broad concerns and allows a foreign government to own Canadian natural resources”). 
foreign capital to develop it all and the promise of higher prices from Asian markets cannot easily be ignored.

The impact of foreign investment on Canada's resource sector has been far reaching. In addition to Canadian businesses benefiting from greater access to capital, foreign investment has also helped stimulate infrastructure projects that will likely prove to have a long term beneficial impact on the Canadian economy. Recently, foreign investors have made significant investments to advance projects from the development stage into production, including infrastructure projects to get production to market. Notably, in October 2012, Phoenix Energy Holdings Limited (a Canadian subsidiary of PetroChina) announced a partnership with TransCanada Corp. to build a CDN\$3 billion pipeline to transport production from its Dover and Mackay River oil sands projects. ${ }^{227}$ Canadian companies with holdings in the area, including Laricina Energy Ltd. and Cenovus Energy Inc., will also potentially benefit from access to capacity on the proposed pipeline. In addition, the numerous proposed LNG projects and ancillary pipelines in British Columbia likely will not be feasible without access to foreign capital and markets. Injections of cash by foreign investors often continue to stimulate business for Canadian companies well beyond the initial investment, and often such additional spending will result in improvements to infrastructure in the energy sector and continue to benefit the Canadian economy. Transactions with foreign investors have become a part of the reality of the Canadian resource sector.

\section{B. STRUCTURING CONSIDERATIONS IN LIGHT OF THE NEW STATE-OWNED ENTERPRISES GUIDELINES}

Despite the recent changes to the SOE Guidelines, we believe that significant opportunities remain for SOEs and other foreign investors in the oil sands through minority acquisitions or joint venture arrangements with minority interests. In addition, there continues to be investment opportunities for SOEs in other areas of the resource sector such as resource intensive shale gas projects and LNG projects. While alternate resource investments such as LNG and shale gas were not specifically addressed in the December 7 Announcements, as discussed above, it is possible that the federal government's review of such investments may become increasingly rigorous, particularly as the level of SOE investment and control in these sectors increases. Because of such uncertainty, we will likely see more non-oil sands transactions being structured to bypass the ICA review process, an example of which was demonstrated almost immediately following the December 7 Announcements. On 13 December 2012, Encana Corp. announced a CDN\$2.2 billion joint venture with PetroChina where PetroChina will acquire a 49.9 percent interest in certain natural gas assets. ${ }^{228}$ This transaction was not reviewable under the ICA because PetroChina acquired a minority interest in the assets. It is likely that the ICA announcement had an impact on how this transaction was structured even though the announced joint venture involved natural gas (not oil sands) assets and was therefore not subject to the exceptional circumstances standard. Develop Grand Rapids Pipeline System,” online: TransCanada Corporation <http://www.transcanada. com/6129.html>. 
In this context, advisors should ask themselves whether there are ways that investors may structure transactions so as to maximize the prospect of approval. It may be necessary for vendors to rank bidders based on the likelihood of ICA review (or successful ICA review), include deal protection language in the transaction documents, and structure the transaction so that it does not constitute an acquisition of control or control in fact or is otherwise outside the jurisdiction of the ICA. For instance, buyers may have less interest in pursuing sole risk development of jointly held assets if the exercise of such rights could themselves trigger an ICA review.

\section{RANKING BIDDERS AND TRANSACTIONS}

From a seller's perspective, if all other things such as proposed purchase prices are equal, the December 7 Announcements suggest a preference for ranking deal risk based on the type of purchaser and transaction (from most preferred to least preferred), as follows:

(1) Canadian (avoids ICA entirely, including the timing and uncertainty issues associated with obtaining approval, SOE and national security concerns);

(2) non-Canadian and non-SOE that does not raise a national security issue (such as, pure private sector enterprise);

(3) non-Canadian that possibly may be influenced by a government and may be considered a SOE;

(4) non-Canadian SOE in permitted sector of investment (non-oil sands or minority investment in oil sands);

(5) non-Canadian SOE in sector that may become a prohibited sector of investment;

(6) non-Canadian SOE in a prohibited sector of investment (such as, oil sands) that is likely to qualify as an "exceptional circumstance";

(7) non-Canadian that raises national security issue;

(8) non-Canadian SOE that raises national security issue;

(9) non-Canadian SOE in a prohibited sector of investment (such as, oil sands) that does not raise national security concerns but is unlikely to qualify as an “exceptional circumstance”; and

(10) non-Canadian SOE that raises national security issue in prohibited sector of investment that is unlikely to qualify as an "exceptional circumstance."

Consequently, lower-ranked prospective purchasers which do not provide sellers with significant economic incentive to take the deal risk presented by their offers will need to compensate for the inherent regulatory risk by offering other mechanisms, including appropriate deal protection language and an appropriate transaction structure. For example, 
a SOE wishing to make an investment in an oil sands business likely will need to content itself with a minority investment that does not trigger acquisition of control or control in fact of the entity or the entity's underlying business and hence, the application of the ICA, or look at doing a joint venture with a non-SOE which will continue to own the majority of the assets subject to such joint venture.

\section{DeAl Protection LANGUAGE}

A seller who wishes to protect against deal failure due to regulatory risk often inserts language in an agreement that requires the investor to make a deposit or agree to pay a "reverse break fee”, and to agree to take whatever steps are necessary to obtain regulatory approval by a certain date, failing which the purchaser will forfeit the deposit or have to pay the fee. However, in the context of obtaining ICA approval, it is questionable from the purchaser's perspective if it should agree to such a provision due to the political nature of the process. In the BHP/Potash case, even generous undertakings were insufficient to obtain approval. Such a provision for obtaining ICA approval is not at all standard in purchase agreements, although it is common in agreements where a purchaser faces difficult issues in obtaining Competition Act approval.

On the other hand, merely offloading the burden of obtaining ICA approval on the purchaser can be risky for the seller. This practice was more customary when obtaining ICA approval was a perfunctory process. However, with approvals often requiring almost the full 75-day review period ${ }^{229}$ to obtain, the minimum risk faced by the parties to a reviewable transaction is the risk of delay of obtaining approval. From there, the risk spectrum increases to the potential for the purchaser having to agree to onerous undertakings, and then ultimately to the possibility of non-approval. In the post-December 7 Announcement environment, it is important for the transaction agreement to reflect the parties' expectations regarding steps the purchaser must take to satisfy its good faith obligations to obtain regulatory approval while apportioning the risk that approval is not obtained despite taking such steps.

There are many provisions that should be considered in allocating and managing regulatory risk. Typically, a seller will want to be involved in the initial contacts with the IRD, contribute to and review drafts of the ICA filing (including the business plan for the Canadian business which is part of the filing), require the purchaser to submit the filing within a pre-determined period after the agreement is signed and the deal announced, be involved in calls and meetings with the IRD, review drafts of undertakings, and generally be "plugged in" to the purchaser's strategy for obtaining a timely approval. While a purchaser might object to laying bare its ICA approval strategy to the seller on the grounds of confidentiality, in our experience the most successful ICA approval processes involve an engaged target or seller, particularly when the target's management will be responsible in any event for implementing many of the operational aspects of the proposed undertakings and is well-positioned to assess the feasibility of the purchaser's plans. 


\section{TRANSACTION STRUCTURE}

As noted above, certain types of transactions have been considered safe harbours for ICA review purposes. These structures may still be reliable, but must now be re-evaluated in light of the December 7 Announcements and the new language of the ICA introduced by Bill C60:

- $\quad$ an acquisition of less than one-third of the voting shares of a corporation or less than a majority of the voting interests of a partnership or joint venture and where there has not been an acquisition of control in fact. ${ }^{230}$ However, Bill C-60 included amendments to the ICA to enable ministerial review of an investment by an otherwise Canadian controlled entity that is controlled in fact by a SOE. ${ }^{231}$ Accordingly, an acquisition of less than one-third of the voting shares of a corporation or less than a majority of the voting interests of a partnership or joint venture may not necessarily constitute safe harbours as either can now be determined to be an acquisition of control;

- $\quad$ an acquisition of between one-third and less than a majority of the voting shares of a corporation where the investor is able to demonstrate it has not acquired control or control in fact (for example, the other shareholder holds 50 percent or more of the voting shares and such other shareholder's influence is dominant or determining). ${ }^{232}$ Again, control in fact becomes more likely above one-third of the voting shares;

- $\quad$ an indirect acquisition of control involving a WTO buyer or seller, that is, the corporation to be acquired is incorporated outside of Canada but in turn holds a Canadian subsidiary. Review only applies where the Canadian business is a cultural business; ${ }^{233}$

- $\quad$ an acquisition of non-voting shares in a corporation or non-voting interests in a partnership; ${ }^{234}$ Control in fact analysis is necessary in this context;

- $\quad$ acquisition of debt, options to acquire voting shares and voting interests, and securities convertible into voting shares or voting interests. ${ }^{235}$ Control in fact analysis is necessary in this context;

- an acquisition of less than all or substantially all of the assets of a Canadian business. ${ }^{236}$ Control in fact analysis is necessary in this context;

ICA, supra note 1 , ss 28(3)(b), (d).

Bill C-60, supra note 122, cl 144(4).

ICA, supra note 1 , s 28(3)(c).

Ibid, s 14.1(4).

Ibid, ss 28(1)(a)-(b).

Ibid, ss 28(1), 30(1).

Ibid, s 28(1)(c). 
- the book value of the Canadian business to be acquired is less than the applicable threshold. ${ }^{237}$ In 2013 this is CDN\$344 million or less than CDN\$600 million "enterprise value" under pending amendments to the ICA;

- the Canadian corporation to be acquired does not carry on a "Canadian business" as defined in the ICA (that is, a corporation which does not have a place of business in Canada, individuals in Canada who are employed or self-employed in connection with the business, and assets used in carrying on the business); ${ }^{238}$

- the Canadian target in fact does not conduct a "business" as defined in the ICA (that is, "any undertaking or enterprise capable of generating revenue and carried on in anticipation of profit") such as an exploration play where there are no recoverable reserves; ${ }^{239}$ or

- an acquisition of an unincorporated branch business (that is, through the acquisition of a foreign entity). ${ }^{240}$

The foregoing situations must be assessed on a case-by-case basis and may lead to some odd results. For example, although the acquisition of less than the majority of the voting interests of a joint venture is not an acquisition of control, the acquisition of all of the voting interests of a partnership which in turn holds a minority interest in a joint venture may be reviewable if the partnership is itself a "Canadian business." ${ }^{241}$ In addition, advisors must be aware of the "step transaction" provisions in section 29 of the ICA. One commentator expressed doubt as to whether, for example, a transaction may be restructured to be indirect so as to avoid the application of the ICA. ${ }^{242}$ However, there is no jurisprudence on this provision. In addition, the national security review provisions of Part IV.1 of the ICA capture a broad swath of transactions which are not otherwise subject to the ICA. ${ }^{243}$ Finally, since the concept of "control in fact" has now been introduced, effectively eliminating the safe harbour that an acquisition of less than one-third of the voting shares of a corporation or less than a majority of the voting interests of a partnership or joint venture will not be subject to ICA review, any comfort previously obtained from the December 7 Announcements that minority investments by SOEs "will continue to be welcome” may now be justifiably diminished. ${ }^{244}$

Ibid, s 14.1(1).

Ibid, s 3.

Ibid.

See ibid, s 28(1)(d).

Sinopec's acquisition of an approximate 9 percent interest in Syncrude from ConocoPhillips was reviewed under the ICA in 2010. The Canadian business was described as "ConocoPhillips Oilsands Partnership II ... a holding company which holds a minority interest in the Syncrude Joint Venture.” See Industry Canada, "June 2010," online at <http://www.ic.gc.ca/eic/site/ica-lic.nsf/eng/lk-31006. html> . Deigan, supra note 15 at 302.

See ICA, supra note 1, s 25.1(c).

"Control in Fact," supra note 204. 


\section{WORKING WITH FOREIGN INVESTORS LOOKING TO INVEST IN THE CANADIAN OIL AND GAS INDUSTRY}

\section{REGULATORY REVIEW AND STAKEHOLDER RELATIONS}

Understanding the new SOE Guidelines and ICA changes will be critical to a foreign investor's decision to make an investment in a Canadian energy play. It has become increasingly apparent that a foreign investor and its Canadian counsel need to develop a comprehensive legal and government and public relations strategy at the outset. Such strategy should focus on potential regulatory hurdles and stakeholder concerns. In our experience, where a foreign investor has been proactive in understanding stakeholder interests, proposed transactions tend to proceed more seamlessly and with less delay. From a vendor's perspective, it will also be in its best interest to ensure that a proposed foreign purchaser or partner engages experienced counsel to effectively navigate the Canadian regulatory regime and stakeholder concerns. As discussed above, arguably the BHP/Potash transaction was ultimately defeated by the significant stakeholder campaign against it. It has become increasingly important for foreign investors to have a clear understanding of the relevant stakeholders and engage a competent team early in the transaction to manage such stakeholder relations.

From the perspectives of both the purchaser and the seller, it is critical for the purchaser to have considered well in advance the key messages of its business plan, and the range of possible undertakings it is prepared to commit to. In our experience, purchasers often do not devote sufficient advance preparation to this task. As a result, valuable time is consumed during the ICA review period in articulating the strategy behind the acquisition in terms that can be reduced to written undertakings.

Finally, it is becoming more and more important for the parties to justify their transaction not only to the IRD and immediate stakeholders but also to the media and the court of public opinion, which can be quite influential in determining whether a prospective buyer has the social licence to make such investment and develop Canada's resources. In this regard, developing the right media and government relationships well in advance of deal announcement, being prepared to explain and defend proposed undertakings and even releasing the essence of proposed undertakings at the time of deal announcement are worth considering, particularly where the transaction involves an iconic Canadian company, or sensitivities such as potential national security and SOE issues. ${ }^{245}$ In this regard, the SOE Guidelines provide in effect a "menu” of possible undertakings which interested observers will inevitably compare to whatever the purchaser is prepared to disclose. ${ }^{246}$

\section{STATE-OWNED ENTERPRISES DETERMINATION}

It will be prudent for both a foreign investor and a vendor proposing a transaction with a foreign investor to conduct an analysis of whether such an investor will be classified as a SOE. Bill C-60 expanded the definition of a SOE, so that whether or not a foreign investor 
will be determined to be a SOE is even more uncertain. As discussed above, it will become increasingly common during a bid process for bidders to be ranked depending on likelihood of ICA review and approval. Whether or not a bidder may be classified as a SOE will need to be taken into account by a vendor looking for deal certainty when reviewing competing bids. As part of the bid process it will be prudent for a vendor to obtain sufficient information from bidders to assess the likelihood that such bidders will be classified as SOEs, as the deal risk created by a reviewable SOE transaction will impact upon the attractiveness of a bid, particularly where such proposed disposition is in the oil sands sector or raises a potential national security concern. It may be useful for a vendor to request certain representations from a potential bidder upfront, to obtain comfort that the potential bidder will not be classified as a SOE, or for the vendor to insist that the potential bidder provide a sufficient degree of transparency for the vendor to make such a determination. Such undertakings or representations could involve background briefings on management and evidence as to how key decision makers, such as directors and officers, are insulated from foreign government influence and able to act independent of state control. If a foreign investor is able to effectively demonstrate insusceptibility to foreign government influence and can provide representations to that effect, it may be more likely that a SOE determination can be avoided.

\section{COMMON FOREIGN INVESTOR CONCERNS}

Beyond a comprehensive analysis surrounding a foreign investor's potential classification as a SOE, it can also be necessary for Canadian counsel and their vendor clients to work with foreign investors and their counsel to educate investors on ownership and operational aspects of the Canadian oil and gas industry and the risks inherent therein. In our experience, foreign investors considering investments into the Canadian resource sector are often concerned about navigating Canadian regulatory regimes, the implications of First Nations' rights, environmental approval processes, the intricacies of Canadian transaction structures, how ownership of the resource is held, challenges thereto, and oil and gas industry standards in general. Particular aspects of joint venture arrangements that are considered the industry norm in North America can be at odds with international practices.

For example, in Canada, purchase and sale agreements involving oil and gas assets and properties provide that environmental liabilities will be assumed by the purchaser and the purchaser will be required to indemnify the vendor for such environmental liabilities, regardless of whether the liability arose prior to or after the closing of the transaction. This absolute indemnity is entirely unique to Canada and understandably causes concern for foreign investors. In addition, during negotiations involving a foreign investor, it may be prudent for the parties to consider the implications of parties being in multiple jurisdictions and the effect on certain provisions in transaction documents. For example, we often see foreign investors creating special purpose companies in Canada to manage the Canadian business. The special purpose company will often be guaranteed by its foreign, parent entity. As such, potential issues may arise in respect of default and dispute resolution and whether or not a party will have to (and be able to) enforce its rights in a foreign jurisdiction.

While these are just two examples of the types of issues that can arise, they demonstrate the importance of all parties to a transaction involving a foreign investor expending the necessary time upfront to engage in a transparent discussion of the intricacies of the 
Canadian oil and gas industry and the risks and issues that cause investors anxiety. Delays at the outset can prove frustrating for vendors looking to get a deal concluded as quickly as possible but ultimately, helping a foreign investor to obtain a clearer understanding of those matters early will expedite the successful closing of a transaction and facilitate the basis of a new long-term relationship in joint venture situations premised on trust, communication, and mutual respect. 